\title{
Um Samra-Um Bakra Shear Zone, Central Eastern Desert, Egypt: Example of Vein -Type Base Metal Mineralization
}

\author{
Ibrahim, M.E. ${ }^{1}$, El- Kalioby, B.A. ${ }^{2}$, El- Sawey ,E. H $^{1}$., Kamar, M.S. ${ }^{1}$, Abu ZeidE.K. ${ }^{1}$ and \\ Ismail, A.M. \\ ${ }^{l}$ Nuclear Materials Authority, P.O. Box 530, Cairo, Egypt \\ ${ }^{2}$ Faculty of science, Ain Shams University, Cairo, Egypt
}

*Corresponding Author: Ibrahim, M.E, Nuclear Materials Authority, P.O. Box 530, Cairo, Egypt

\begin{abstract}
Um Samra-Um Bakra area located in the southern part of the Central Eastern Desert of Egypt and covered by; 1) ultramafic rocks and volcanogenic sediments), 2) igneous rocks (syn-orogenic granites, isotropic gabbros and post-orogenic granites and 3) post-granitic dykes (basic and intermediate) and veins (black-, red jasper and milky quartz). Um Samra-Um Bakra shear zone strikes $N 70^{\circ} \mathrm{W}-S 70^{\circ} \mathrm{E}$ and dipping $45^{\circ} / \mathrm{SSW}$ and ranges from 10 to $500 \mathrm{~m}$ in thickness and extends $10 \mathrm{~km}$ in length.

Three generations of silica veins differ in color, mineralization and age are intruded the shear zone. The milky quartz vein is the youngest silica phase, barren, running WNW and dipping $70 \%$ SSW direction. The red jasper (second phase) has $N 60^{\circ}-76^{\circ} \mathrm{W}$ trend, dipping $45^{\circ} / \mathrm{SSW}$. The oldest phase is represented by black jasper trending $N 75^{\circ} \mathrm{W}$ and dipping $50^{\circ}-65^{\circ} / \mathrm{SSW}$. The black jasper veins richer in $\mathrm{Ni}, \mathrm{Cr}, \mathrm{Zn}, \mathrm{Cu}, \mathrm{Au}$ and $\mathrm{Y}$ than red one.

The mineralogical studies at Um Samra - Um Bakra shear zone confirm the presence of three mineralization stages through hydrothermal solutions. The first stage (high temperature) distinguishes by the formation of native Au associated with hypogene primary sulfide minerals such as pyrite, galena, sphalerite and nickel. The second stage (lower-temperature) illustrates by the formation of secondary minerals; uranium, copper minerals (atacamite, paratacamite, crysocolla and cuprite), zincite, cassiterite, wolframite, Ni-chromite and Cr-spinel. The third stage is related to carbonate facies (calcification, fluoritization) formed after the oxidation (supergene alteration).
\end{abstract}

Keywords: Um Samra, Um Bakra, Shear zone, Base metals, Vein type.

\section{INTRODUCTION}

Most vein deposits occur in fault or fissure openings or in shear zones within country rock. Many valuable ore minerals, such as native gold, silver or metal sulfides are deposited along with gangue minerals, mainly quartz and/or calcite, in a vein structure (Haynes, 1993).

Vein-type ore deposits were widely distributed over the Eastern Desert of Egypt and enclosing mineralization such as $\mathrm{Sn}-\mathrm{W}$ mineralization at the Mueilha peraluminous granites (Abdalla et al. 2008), fluorite and beryl at Homr Akarem calc-alkaline granites (Hassan, and El Shatoury, 1976), Vein-type uranium mineralization are structurally controlled, for example Gabal El-Missikat, Gabal El- Erediya at the central Eastern Desert (Bakhit, 1978; Abu Dief,1985; Hussein et al., 1986; Bakhit and Meleik, 1990; Hussein and Sayyah, 1991, Abu-Deif and El-Tahir, 2008) and Gabel El Sella peraluminous granites at the south Eastern Desert (Ibrahim et al., 2003).

Granitoid rocks have been differentiated into two broad categories, namely older and younger granitoids, based upon their composition and age relationships (El-Ramly, 1972). The older granitoids are compositionally extended ranging from quartz diorite to granite (trondhjemites, tonalites and granodiorites). They were emplaced during the main orogenic stage between 800 and $614 \mathrm{Ma}$ (Stern and Hedge,1985 and Hassan and Hashad, 1990).The younger granitoids (monzogranites, syenogranites and alkali feldspar granites) were emplaced during the post orogenic stage between 610 and $550 \mathrm{Ma}$ (Moghazi et al., 1998).

Gabel (G.)Um Samra and G. Um Bakra are a part of the Arabian Nubian Shield lies at the southern part of the central Eastern Desert of Egypt. Kabesh et al.,(1982), Shazly et al.,(1998) and Abdel 
Monem et al.,(1999) studied the petrographical and geochemical characteristics of G. Um Samra and G. Um Bakra granites. The two plutons are alkali feldspar granites associated with Au-, Ag- and barite mineralized quartz veins. Arsenopyrite, pyrite, chalcopyrite, stibnite and rutile represent the hypogene minerals.

Many land marks exist in the area under consideration; the most important of them are G. Um Samra (908m, a.s.1) and G. Um Bakra (901m, a.s.l) which represent the highest topographic features. Um Samra-Um Bakra area occupies the area between latitudes $25^{\circ} 15^{\circ}$ to $25^{\circ} 18^{\circ} \mathrm{N}$ and longitudes $34^{\circ} 5^{\circ}$ to $34^{\circ} 12^{`} \mathrm{E}$ (Fig. 1).

This paper throws some lights on the geologic setting, mineralogy and ore microscopic studies on a new shear zone cropping out Um Samra - Um Bakra area,

\section{Methodology}

For the mineralogical studies, the collected samples were crushed, grinded, quartered and sieved $(800 \mu \mathrm{m}-63 \mu \mathrm{m})$. Most of the samples in previous grain size were concentrated by using wufly table to remove the light minerals. The separation of magnetite was achieved by hand magnet. This heavy fraction was subjected to the heavy liquid separation using bromoform solution (sp. gr. $2.81 \mathrm{~g} / \mathrm{cm} 3$ ) to separate the heavy minerals. The residue fractions were subjected to the magnetic fractionation using Frantz isodynamic magnetic separator Model LB-1 .The separated fractions were carefully picked under the binocular stereomicroscope depending on the grain shape, color, hardness, luster and crystal habit.

Identification of minerals was achieved by three techniques at Nuclear Materials Authority labs (NMA): a) A Nickon polarized microscope prepared with mechanical stage is used for thin section studies and minerals identification, textures and modal analysis. b) X-ray diffraction technique (XRD), using Philips PW 3710/31 diffractometer, scintillation counter, Cu-target tube and Ni filter at $40 \mathrm{KV}$ and $30 \mathrm{MA}$ and c)The Environmental Scanning-Electron Microscope (ESEM model Philips XL30) supported by energy dispersive spectrometer (EDX) unit was used at 25-30 KV accelerating voltage, 1-2 mm beam diameter and 60-120 second counting time.

The samples were prepared for (XRF) measurements to determine major and trace elements at Atomic Energy Authority Labs. In laboratory, the samples were grinded to (-200 mesh) in particle size. The preparation of pressed powder pellets are achieved by filling an alumina cup with $9 \mathrm{gm}$ of crystalline boric acid covered by $1 \mathrm{gm}$ of the grounded sample.

\section{Geologic SetTing}

The Um Samra-Um Bakra area is covered by; 1) ophiolitic ultramafic and related rocks, and volcanogenic sediments), 2) igneous rocks (syn-orogenic granites, isotropic gabbros and postorogenic granites and 3) post-granitic dykes (basic and intermediate) and veins (black, red jasper and milky quartz) as shown in figure (1).

- Ophiolitic Ultramafic Rocks are wide distribution in the Eastern Desert of Egypt and typically of alpine-type ranging in composition from peridotite to dunite rocks and enriched with chromite pockets (Saleh et al., 2015), these rocks are interpreted as dismembered blocks and fragments of an ophiolitic rocks. They represented in the study area by serpentinites and talc carbonates.

- Volcanogenic Sediments Outcrop in the northern area and intruded by syn- and post-orogenic granites through intrusive sharp contacts (Fig.1). The intercalation between volcanoclastic and volcano-sedimentary is a dominant character in the Egyptian Shield (Kroner et al., 1987). The studied volcanogenic rocks are fine- to medium -grained, banded, laminated and ranging in composition from fine tuffs through banded and lithic crystals tuffs to lapilli tuffs and intercalated with banded iron ore (BIF).

- Syn-Orogenic Granites are equivalent to syn-orogenic plutonites, older granites (Akaad and Noweir, 1980) and subduction-related granites (Hussein et al, 1982). They consist of different varieties, ranging in composition from diorites, quartz diorites through tonalities to granodiorites without inferred contacts in between. They crop out at the NW corner of the area (Ibrahim, 2001). 
- Isotropic Gabbros Crop out along the SW and NE border of the area and occur either as roof pendants uplifted by the post-orogenic granites or as xenoliths hosted in the younger rocks. They intruded the syn-orogenic granites with sharp intrusive contact and intruded by the post-orogenic granites. Isotropic gabbros are represented by olivine gabbro and composed mainly of plagioclase, olivine, pyroxene and hornblende. Zircon and opaques are accessory minerals. Actinolite, epidote and saussurite are secondary minerals.

- Post-Orogenic Granites Crop out at G. Um Samra-Um Bakra (Fig.1) and vary in composition from monzogranites through syenogranites to alkali feldspar granites with gradational contacts. They cut by major WNW-ESE shear zone.

- The monzogranites are medium to coarse grained, pinkish in color and composed essentially of K-feldspars (39.7 in vol. \%), plagioclase $\left(\mathrm{An}_{12-14}\right)$ (32 in vol. \%), quartz (24.8 in vol. \%) and biotite (3.8 in vol. \%). Sphene and opaques are accessories; while muscovite and chlorite are secondary minerals. The presence of two feldspars (perthite and plagioclase) suggests that this granite is mostly subsolvus and crystallized under high water pressure (Greenberg, 1981).

$\circ$ The syenogranites are medium to coarse-grained with pinkish to reddish in color and composed mainly of K-feldspars (orthoclase and microcline perthite) (50 in vol. \%), quartz (28 in vol. \%), albite to oligoclase in composition $\left(\mathrm{An}_{9-14}\right)(20.6$ in vol. \%) and biotite $(0.5$ in vol. \%). Zircon, allanite, sphene and opaques are accessories.

- The alkali feldspar granites are medium- to coarse-grained, equigranular in texture, pinkish to reddish in color and composed mainly of microperthite and microcline microperthite 72.5 in vol. \%), quartz (26.1 in vol. \%) ,biotite, muscovite and albite existed in minor amounts. Flame, patchy; string perthite and patchy antiperthite are common. Zircon, sphene, fluorite and opaques are accessory minerals.

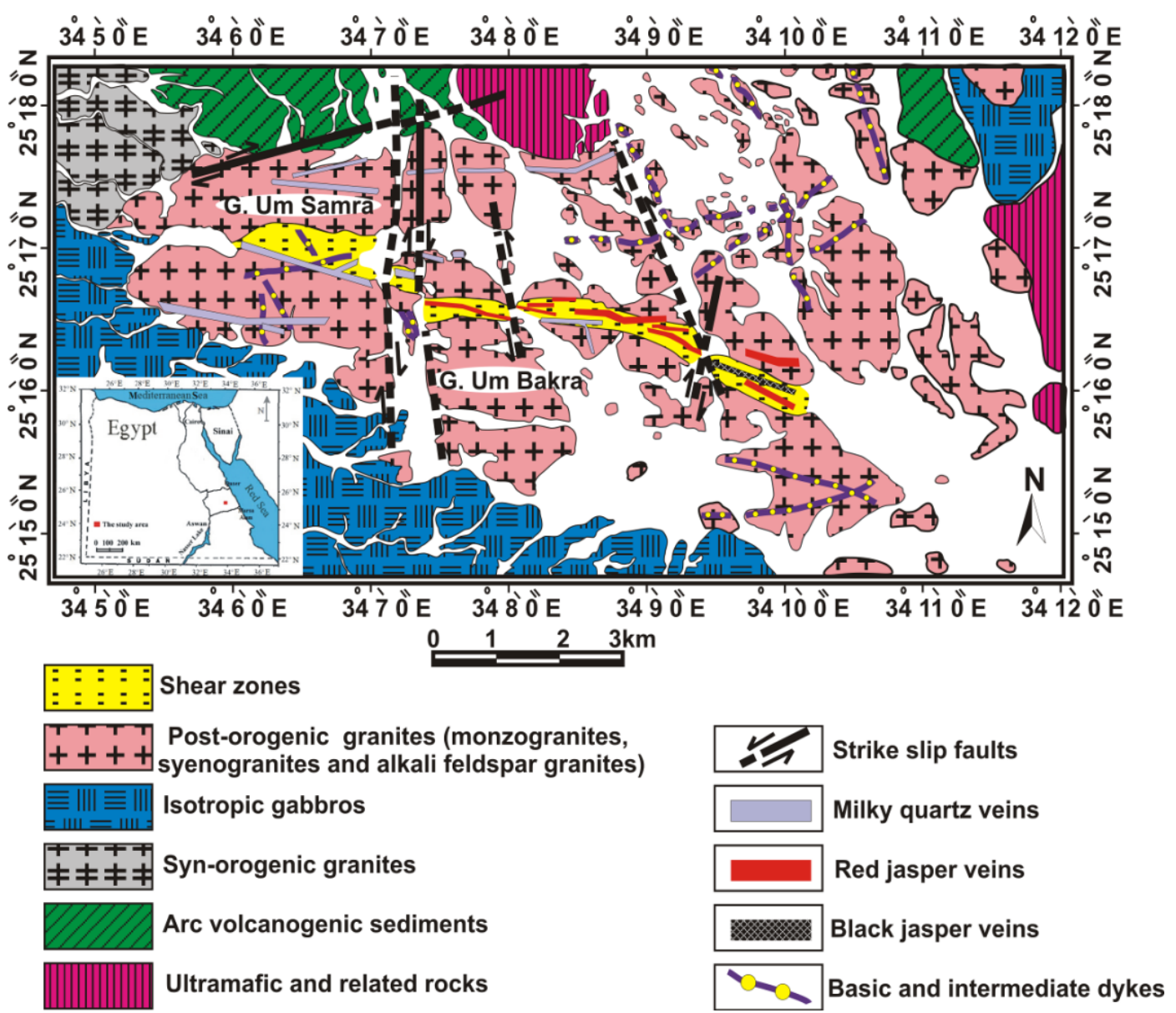

Fig.1. Geological map of Um Samra-Um Bakra shear zone, Eastern Desert, Egypt.

- Post Granite Dykes running in WNW, ENE, NNE and NE directions (Fig.1) with sharp contacts with their host rocks. They are represented by basic and intermediate dykes as follows: 
$\circ$ Olivine basalt dykes strike N-S to NNW-SSE and dip $50^{\circ} / \mathrm{E}$ to ENE respectively, varying in width $(0.5-2 \mathrm{~m})$ and in length $(100 \mathrm{~m}-3.3 \mathrm{~km})$. They are composed mainly of labradorite $\left(\mathrm{An}_{60}\right.$ 68), olivine and hornblende. They are characterized by amygdaloidal texture filled by iron oxide and quartz.

○ Dolerite dykes vary in width $(0.5-2 \mathrm{~m})$ and in length $(0.3-0.5 \mathrm{~km})$. They striking ENE-WSW and dipping $65^{\circ} / \mathrm{SSE}$ direction and composed mainly of andesine to labradorite $\left(\mathrm{An}_{48-56}\right)$, hornblende and clinopyroxene. Plagioclase laths form with pyroxene doleritic texture. Amygdaloidal cavities filled with calcite.

- Porphyritic andesite strikes E-W and dips $60 \%$, ranging in width between 0.5 and $1 \mathrm{~m}$. they are composed mainly of phenocrysts of plagioclase and hornblende and rare biotite .

- Post Granite Veins two types of milky quartz veins recorded in the study area; a) barren quartz veins (BQ) are limited only to the Um Samra - Um Bakra shear zone; b) mineralized quartz veins (MQ) intruded the fresh granites; vary from white to pale gray in color, sometimes display lamination on the $\mathrm{cm}$ scale and stained by iron oxides. The later veins ranging between $0.3 \mathrm{~m}$ and $3 \mathrm{~m}$ in width (Fig.2), running ENE, WNW, E-W and N-S and dipping $40^{\circ}-80^{\circ}$ / SSE, SSW, S and $\mathrm{E}$ direction respectively. They show druses in the vuggy parts with visible pyrite specks, galena and iron oxides. Ore microscopic study reveals the presence of pyrite, arsenopyrite, covellite, galena and bornite. Pyrite is the main ore mineral in the MQ veins. Sometimes pyrite occurs in aggregates along quartz fractures (Plate 1a) and transformed into pyrrhotite and iron minerals (Plate $1 \mathrm{~b}$ ). Covellite, bornite and magnetite existed as oxidation product of disseminated pyrite (Plate 1c). Galena present in triangular pitting (Plate 1d).
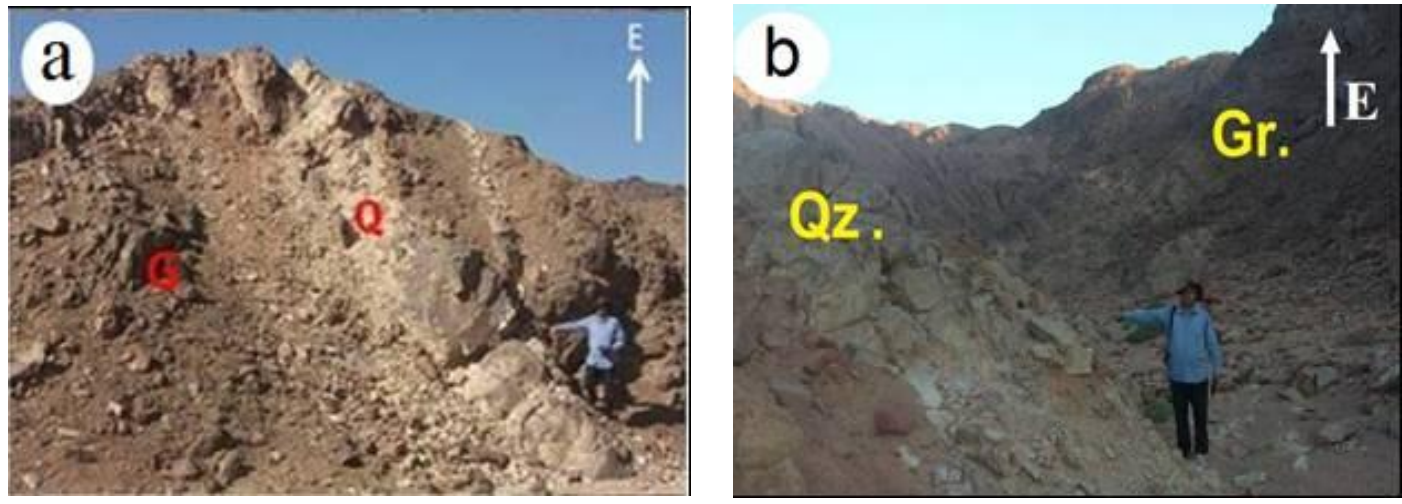

Fig.2. Photo showing ( $a \& b)$ mineralized quartz veins intruded Um Samra-Um Bakra granites.

\section{UM SAMRA- UM BAKRA SHEAR ZONE}

Um Samra-Um Bakra shear zone strikes $\mathrm{N} 70^{\circ} \mathrm{W}$, dips $45^{\circ} / \mathrm{SSW}$, ranges from 10 to $500 \mathrm{~m}$ in width, extends more than about $10 \mathrm{~km}$ in length and cuts alkali feldspar granites. The shear zone is highly structure controlled, fine-grained, ferruginous, kaolinitized and reddish pink to grayish in color (Fig. 3). The shear zone (WNW-ESE) dissected by N-S and NNE strike-slip faults, dextral and sinistral sense of movement, forming grabben and horst structures. Due to the repeated magmatic activities, reactivated tectonic trends especially WNW- ESE and NNE-SSW and their associated fluids, many alteration halos are observed. The common presence of silica veins, clay minerals, hematite, calcite and fluorite manifesting silicification, kaolinitization, hematitization, carbonitization and fluoritization processes respectively along the shear zone. Yellow radial U- minerals (up to $1 \%$ ) visible by nicked eyes were recorded coating the fractures in the ferruginated granites. The later bordered on the two sides by milky quartz veins, which play as septa for U- minerals migration. Meta-autunite $\left[\mathrm{Ca}\left(\mathrm{UO}_{2}\right)_{2}\right.$ $\left(\mathrm{PO}_{4}\right)_{2} \cdot 3 \mathrm{H}_{2} \mathrm{O}$ ] occurs as lemon-yellow to greenish yellow, subhedral crystals formed as dehydration pseudomorphs after autunite (Fig.4a) and usually associated with kasolite $\left[\mathrm{Pb}\left(\mathrm{UO}_{2}\right) \mathrm{SiO}_{4}\left(\mathrm{H}_{2} \mathrm{O}\right)\right]$. Phurcalite $\left[\mathrm{Ca}_{2}\left(\mathrm{UO}_{2}\right)_{3}\left(\mathrm{PO}_{4}\right) 2(\mathrm{OH})_{4} \cdot 4 \mathrm{H}_{2} \mathrm{O}\right]$ occurs as light brown subhedral to anhedral crystals of calcium uranium phosphate (Fig. 4b) and usually associated with iron oxides. The latest event invades the WNW-ESE shear zone was the intrusion of silica and jasper veins with different magnitude. The excess of released quartz can migrate as colloidal silica to precipitate later in the tension fractures as jasperoid vein at upper structural levels under low temperature condition. 
Um Samra-Um Bakra Shear Zone, Central Eastern Desert, Egypt: Example of Vein -Type Base Metal Mineralization
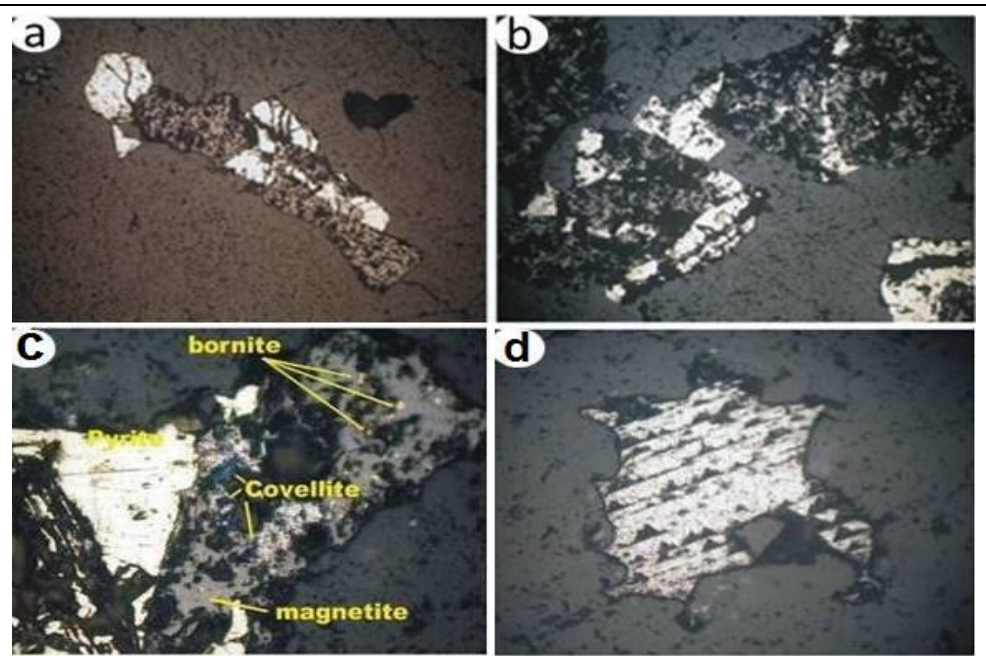

Plate1. Photomicrographs of mineralized quartz vein showing; a) aggregate of pyrite along fracture, $X=10, b$ ) pyrite transformed into pyrrhotite and iron mineral, $X=10 . c)$ covellite, bornite and magnetite as oxidation product of pyrite, $X=10$ and d) triangular pitting of galena, $X=20$.

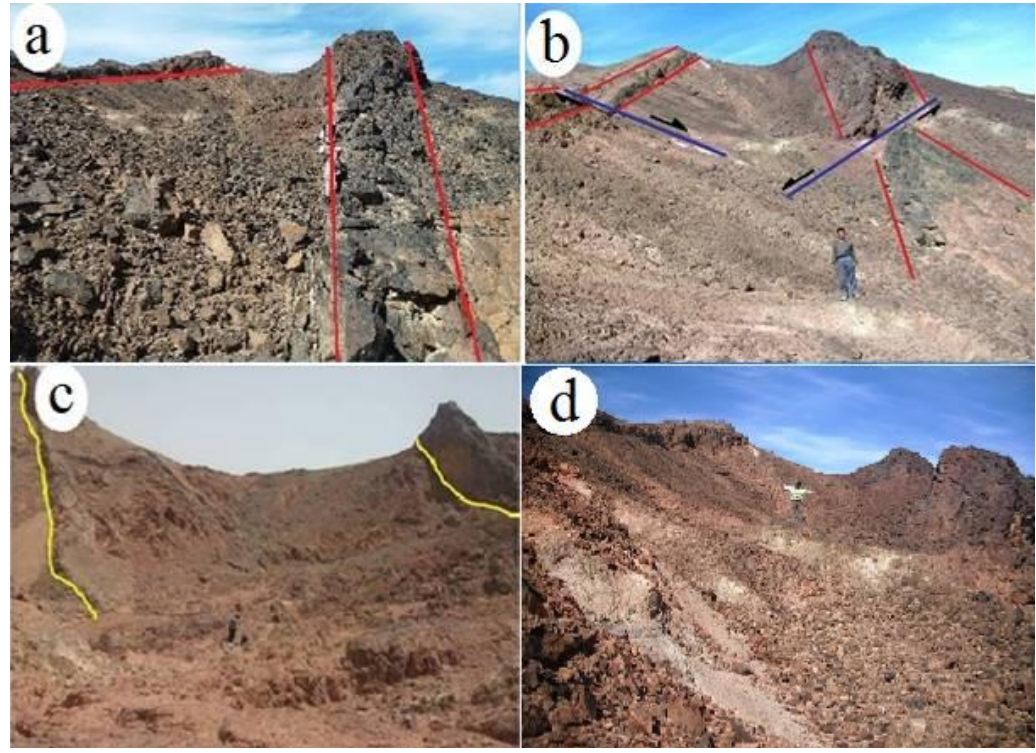

Fig.3. WNW-ESE Um Samra-Um Bakra shear zone with jasperoid silica veins.
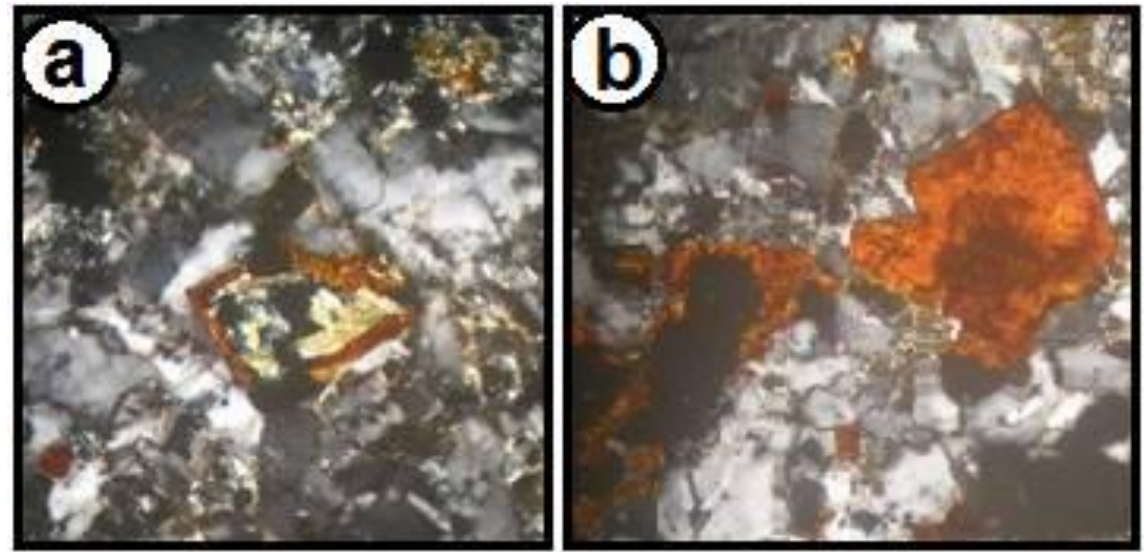

Fig.4. Photomicrographs showing; a) meta-autunite crystal surrounded by phurcalite mineral in altered granites. C.N., $X=40$ and b) phurcalite mineral associated with iron oxide in altered granites. C.N., $X=40$.

Silicification along the main shear zone has a noticeable amount of liberated secondary silica occurs as fine crystals associated with the large primary quartz crystals and characterized by the existence of three generations of silica veins differ in trace elements distribution, color, mineralization and age as follows: 
- The milky quartz veins are the youngest event, mainly barren, running WNW and dipping $70 \%$ SSW direction, highly brecciated (2-5 Km in length, $0.25-3 \mathrm{~m}$ in width) and widespread only at the southern border of the shear zone.

- The red jasper veins (second phase) have E-W, WNW, NW and NE trends (Fig.3), dipping 50$75^{\circ} / \mathrm{N}$ or/ S, $45^{\circ} / \mathrm{SSW}, \mathrm{SW}$ and SE direction respectively. They fragmented, discontinuous, $(7 \mathrm{~km}$ in length, 0.30-3 m in width) and rich in $\mathrm{Cr}, \mathrm{Ni}, \mathrm{Sn}, \mathrm{Zn}$ and $\mathrm{Cu}$-mineralization. Some parts of red jasper are characterized by vugs (physical trap) that are filled by mineralization. These veins exhibit combinations of more than one style; orbicular and brecciated.

- The black jasper (oldest one) extends $1.8 \mathrm{~km}$ in length, $0.5-10 \mathrm{~m}$ in width, trends $\mathrm{N} 45^{\circ} \mathrm{W}$, dips $50^{\circ}-65^{\circ} / \mathrm{SW}$ (Fig. 3), and rich in $\mathrm{Cr}, \mathrm{Ni}, \mathrm{Cu}$ and $\mathrm{Au}$ mineralization. They are concentrated only in the eastern part of G. Um Bakra and less abundant in length than milky and red jasper veins. The black jaspers (plate 2a) are vuggy than milky and red silica veins and these vugs filled by calcite minerals. The apical parts of the veins are intensely weathered, oxidized, brecciated fragments and decomposed to forming gossans. Petrographically, quartz occurs as cryptocrystalline and polycrystalline forming spherulitic texture. Iron oxide associated with quartz and sometimes forming network or needle (Plate 2b). Cr- spinel with blood red color was observed and having darker boundaries with quartz (Plate 2c). Ore microscopic study reveals the presence of chromite and magnetite minerals. Fire assay for gold content gives $1.04 \mathrm{~g} /$ ton .Chromite occurs as anhedral crystal associated with magnetite (Plate 2d). Chromite existed in different forms; zoned veinlet or disseminated specks (Plate 2e \& f).

\section{GeOchemical Results}

The altered granites along the shear zone are enriched in most major oxides $\left(\mathrm{Fe}_{2} \mathrm{O}_{3}, \mathrm{TiO}_{2}, \mathrm{MnO}, \mathrm{MgO}\right.$, $\mathrm{CaO}$ and $\mathrm{P}_{2} \mathrm{O}_{5}$ ) except $\mathrm{SiO}_{2}$ and $\mathrm{Na}_{2} \mathrm{O}$ than fresh granites (Fig.5) manifesting ferrugination, calcification, desilicification and illitization. Also the fresh granites are depleted in most trace elements ( $\mathrm{Ni}, \mathrm{Cr}, \mathrm{Sr}, \mathrm{Zr}, \mathrm{Y}, \mathrm{Ga}, \mathrm{Zn}, \mathrm{Pb}$, and $\mathrm{Cu}$ ) except $\mathrm{Nb}$ than altered ones. Based on major element data, the main characteristic features of the altered granites are its higher $\mathrm{Fe} / \mathrm{Mg}$ ratio (15 av.), lower $\mathrm{SiO}_{2}$ (av. $52.8 \%$ ) and $\mathrm{Na}_{2} \mathrm{O} / \mathrm{K}_{2} \mathrm{O}$ (av. 0.16) than fresh granites (Table 1). The black jasper veins are more rich in $\mathrm{Ni}, \mathrm{Cr}, \mathrm{Zn}, \mathrm{Cu}$ and $\mathrm{Y}$ than red one( Fig.6 ).

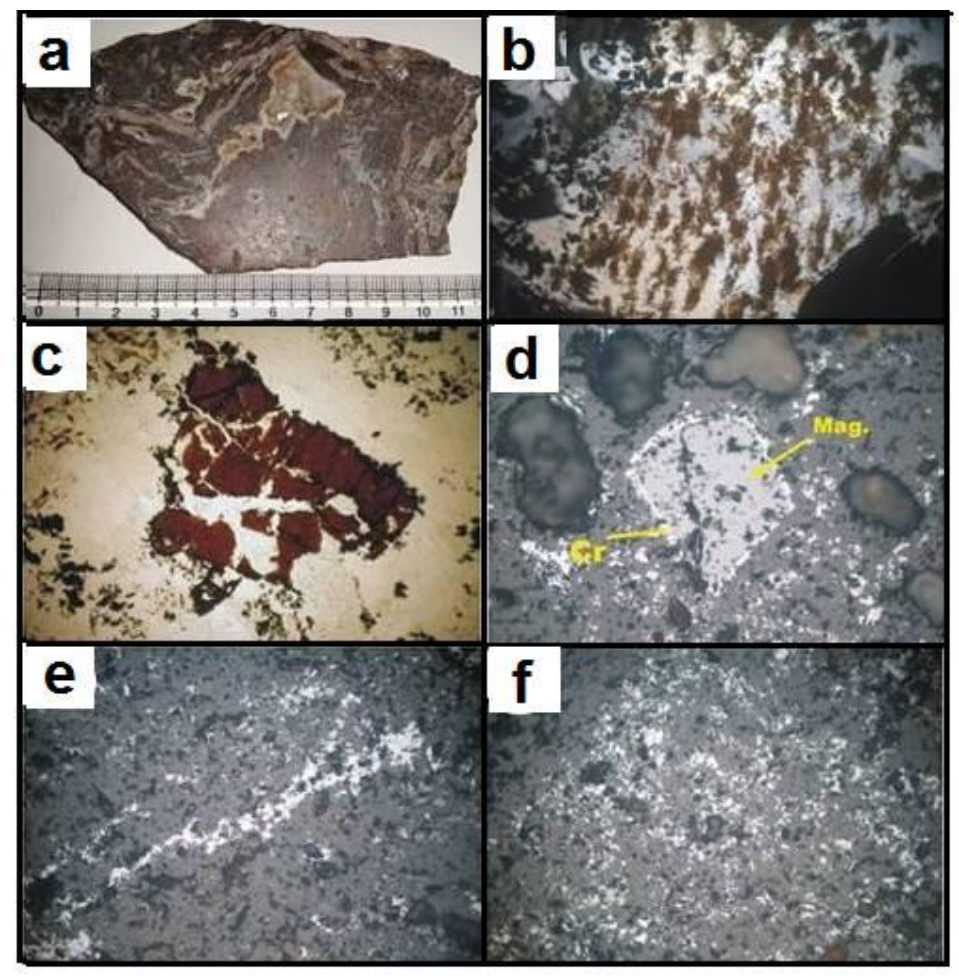

Plate2. Photomicrographs in black jasper vein showing; a) brecciated jasper vein with vugs. b) hematitization in quartz and iron oxide occurs as needles. C.N., $X=40$, c) blood red, Cr spinel having darker boundaries in $B J V(P P L), X=20, d)$ chromite (cr) in rim and magnetite (mag) in core in BJV. $X=40$, e) veinlet of chromite and groundmass of magnetite in BJV, X=40 and f) disseminated specks of chromite in $B J V, X=40$. 
Um Samra-Um Bakra Shear Zone, Central Eastern Desert, Egypt: Example of Vein -Type Base Metal Mineralization
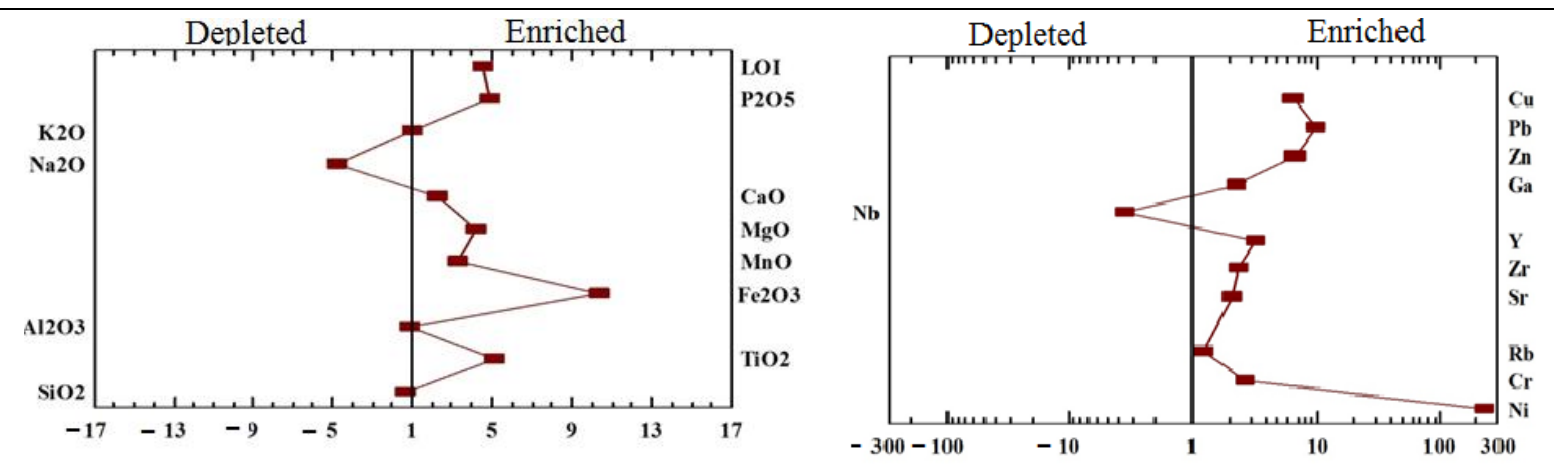

Fig.5. The enrichment and depletion of major oxides and trace elements of altered granites to the fresh granites samples

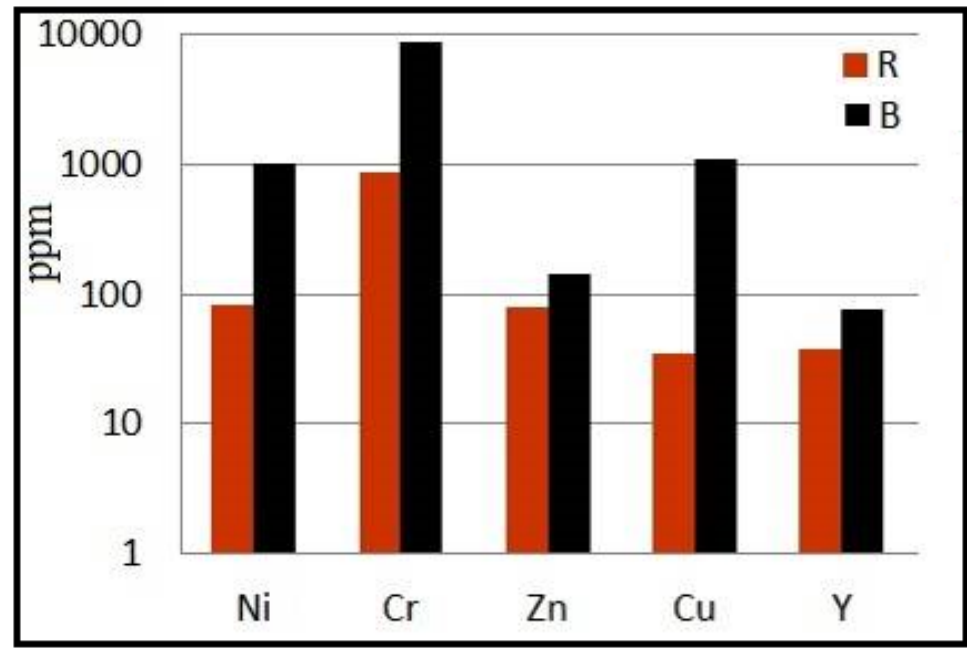

Fig.6. Bar-diagram showing the trace elements distribution of red $(R)$ and black(B) jasper

Table1. Chemical analysis of major oxides and trace elements of Um Samra-Um Bakra area

\begin{tabular}{|c|c|c|c|c|c|}
\hline \multicolumn{6}{|c|}{ Major oxides $\%$} \\
\hline & & Fresh granite & Altered granite & Red jasper & Black jasper \\
\hline \multirow[t]{2}{*}{$\mathrm{SiO} 2$} & Range & $69.22-75.33$ & $23.14-72.09$ & $70.3-92.53$ & $72.93-91.27$ \\
\hline & Average & 72.9 & 52.8 & 84.2 & 82.7 \\
\hline \multirow[t]{2}{*}{$\mathrm{TiO} 2$} & Range & $0.01-0.29$ & $0.28-2.46$ & $0.01-0.22$ & 0.0 \\
\hline & Average & 0.2 & 1.08 & 0.2 & 0.0 \\
\hline \multirow[t]{2}{*}{$\mathrm{Al} 2 \mathrm{O} 3$} & Range & $12.35-15.4$ & $10.37-18.02$ & $0.69-14.85$ & 0.69 \\
\hline & Average & 13.7 & 12.7 & 6.8 & 0.8 \\
\hline \multirow[t]{2}{*}{$\mathrm{Fe} 2 \mathrm{O} 3$} & Range & $0.08-2.91$ & $2.10-45.77$ & $1.39-4.97$ & $4.46-22.54$ \\
\hline & Average & 1.9 & 19.8 & 3.4 & 13.4 \\
\hline \multirow[t]{2}{*}{$\mathrm{MnO}$} & Range & $0-0.08$ & $0-0.75$ & $0.01-0.03$ & $0.01-0.04$ \\
\hline & Average & 0.03 & 0.1 & 0.03 & 0.03 \\
\hline \multirow[t]{2}{*}{$\mathrm{MgO}$} & Range & $0.13-0.65$ & $0.24-7.23$ & $0.29-1.75$ & $0.19-0.60$ \\
\hline & Average & 0.31 & 1.32 & 0.806 & 0.442 \\
\hline \multirow[t]{2}{*}{$\mathrm{CaO}$} & Range & $0.45-2.55$ & $1.26-4.4$ & $0.31-0.76$ & $0.01-1.74$ \\
\hline & Average & 1.1 & 2.6 & 0.6 & 0.5 \\
\hline \multirow[t]{2}{*}{$\mathrm{Na} 2 \mathrm{O}$} & Range & $3.15-4.34$ & $0.12-3.34$ & $0.05-2.2$ & $0.05-0.12$ \\
\hline & Average & 3.7 & 0.8 & 0.6 & 0.08 \\
\hline \multirow[t]{2}{*}{$\mathrm{K} 2 \mathrm{O}$} & Range & $4-6.70$ & $1.84-7.78$ & $0.1-6.96$ & $0.04-0.09$ \\
\hline & Average & 5 & 5 & 3 & 0.06 \\
\hline \multirow[t]{2}{*}{$\mathrm{P} 2 \mathrm{O} 5$} & Range & 0.020 .16 & $0.01-1.23$ & $0.07-0.48$ & $0.02-0.04$ \\
\hline & Average & 0.08 & 0.39 & 0.224 & 0.032 \\
\hline \multirow[t]{2}{*}{ L.O.I. } & Range & $0.04-0.85$ & $0.8-2.80$ & & \\
\hline & Average & 0.31 & 1.43 & & \\
\hline \multirow[t]{2}{*}{ Total } & Range & 99.73-99.9 & $93.22-99.91$ & $99.36-99.92$ & $97.45-99.01$ \\
\hline & Average & 100 & 98.42 & 99.7 & 98.288 \\
\hline
\end{tabular}


Um Samra-Um Bakra Shear Zone, Central Eastern Desert, Egypt: Example of Vein -Type Base Metal Mineralization

\begin{tabular}{|c|c|c|c|c|c|}
\hline \multicolumn{6}{|c|}{ Trace elements (ppm) } \\
\hline & & Fresh granite & Altered granite & Red jasper & Black jasper \\
\hline \multirow[t]{2}{*}{$\mathbf{N i}$} & Range & $0.0-55$ & 0-18095 & $0-409$ & 314-1501 \\
\hline & Average & 10 & 2322 & 81 & 1004 \\
\hline \multirow[t]{2}{*}{$\mathrm{Cr}$} & Range & 233-485 & 113-2409 & 294-2689 & $3490-12898$ \\
\hline & Average & 296 & 798 & 853 & 8575 \\
\hline \multirow[t]{2}{*}{$\mathbf{R b}$} & Range & 83-210 & $0-392$ & $0.0-1161$ & 0.0 \\
\hline & Average & 147. & 128 & 289 & 0.0 \\
\hline \multirow[t]{2}{*}{$\mathbf{S r}$} & Range & 17-507 & 73-58 & 8-127 & 0-17 \\
\hline & Average & 142 & 278 & 74 & 7 \\
\hline \multirow[t]{2}{*}{$\mathbf{Z r}$} & Range & 89-659 & 196-1873 & $0-466$ & $\mathbf{0 . 0}$ \\
\hline & Average & 316 & 759 & 238 & 0.0 \\
\hline \multirow[t]{2}{*}{$\mathbf{Y}$} & Range & 16-102 & 84-512 & $0-79$ & $0-142$ \\
\hline & Average & 69 & 220 & 38 & 77 \\
\hline \multirow[t]{2}{*}{ Nb } & Range & $14-56$ & $0-62$ & 0-35 & $\mathbf{0 . 0}$ \\
\hline & Average & 36 & 10 & 11 & 0.0 \\
\hline \multirow[t]{2}{*}{ Ga } & Range & $22-45$ & $0-151$ & $0-59$ & 0.0 \\
\hline & Average & 32 & 73 & 24 & 0.0 \\
\hline \multirow[t]{2}{*}{ Zn } & Range & 16-145 & 0-2409 & $32-169$ & $56-281$ \\
\hline & Average & 78 & 528 & 80 & 144 \\
\hline \multirow[t]{2}{*}{$\mathbf{P b}$} & Range & $0-52$ & 0-684 & $0-173$ & 0.0 \\
\hline & Average & 16 & 157 & 45 & 0.0 \\
\hline \multirow[t]{2}{*}{$\mathbf{C u}$} & Range & 0-32 & 0-210 & $0-80$ & 431-2045 \\
\hline & Average & 4 & 26 & 35 & 1107 \\
\hline \multirow[t]{2}{*}{ Co } & Range & 0.0 & 0.0 & 0.0 & 0-558 \\
\hline & Average & 0.0 & 0.0 & 0.0 & 371 \\
\hline \multirow[t]{2}{*}{ Mo } & Range & 0.0 & 0.0 & 0-127 & 0.0 \\
\hline & Average & 0.0 & 0.0 & 25 & 0.0 \\
\hline \multirow[t]{2}{*}{ As } & Range & 0.0 & 0.0 & 0-2098 & 0.0 \\
\hline & Average & 0.0 & 0.0 & 419 & 0.0 \\
\hline \multirow[t]{2}{*}{$\mathbf{U}$} & Range & $2-9$ & $32-8600$ & 0.03-8 & $4-9$ \\
\hline & Average & 5 & 2185 & $\begin{array}{l}0.04 \\
\end{array}$ & 5 \\
\hline
\end{tabular}

\section{Alterations}

Two phases of hydrothermal alterations; acid and alkaline were distinguished in the shear zone resulting in Kaolinization and ferrugination processes as illustrated below:

Kaolinization indicates that the rocks were affected by acidic solution with low temperature varying from 200 to $250{ }^{\circ} \mathrm{C}$ (Helgeston, 1974). Kaolinitization process causes an increase in alumina $(18.02 \%)$ at the expense of the other major oxides (Table1). Kaolinization affects sheared granites along the shear zone by the formation of clay minerals and adsorbed secondary U- minerals (metaautunite, kasolite and phurcalite).

Acidic alteration of biotite produces illite + quartz, while magnesium, iron and fluorine are dissolved in hydrothermal fluids (Pirajno, 1992). These solutions caused the alteration of the feldspars and micas to clay minerals (Fig.7). Similarly, the anorthite component of plagioclase was transformed to (clay minerals) (Hemley and Jones, 1964; Pirajno1992) and frees $\mathrm{Ca}^{+3}$ ions transported also by the hydrothermal solution. The free $\mathrm{Al}^{+3}$ increase the alumina in the clay mineral. This kind of alteration by acid solution is responsible for transportation and redeposition of uranium and base metals mineralization in WNW-ESE shear zone which acts as a good trap.

Ferrugination causes increase in total $\mathrm{Fe}^{+2} \mathrm{O}^{+3}$ content $\left(\mathrm{FeO}^{\mathrm{t}}=2.10 \%\right.$ to $\left.45.77 \%\right)$ at the expense of other oxides. The strong alkaline solution may precipitate $\mathrm{Fe}^{+3}$ and $\mathrm{U}^{+6}$ within the shear zones in the form of iron oxy-hydroxides rich in uranium (Cuney et al., 1984). Sheared granite samples stained by Fe - oxides adsorb U- minerals at the main shear zone. Ferrugination is represented mainly by hematite and goethite minerals (Table 2 and Fig. 8). Oxygen may combine with iron to produce hematite forming hematitic alteration.

Carbonitization: The common presence of calcite manifesting carbonitization process along the shear zone. Carbonate minerals are common in serpentinites and related rocks, and isotropic gabbros . 
Fluoritization: Fluorite was emplaced through the fractures and fissures in altered granite along the shear zone. The released $3 \mathrm{Ca}^{2+}$ and $6 \mathrm{~F}-$ during illitization of the anorthite and biotite may combine together forming fluorite which is observed within the shear zone associate with U- minerals.

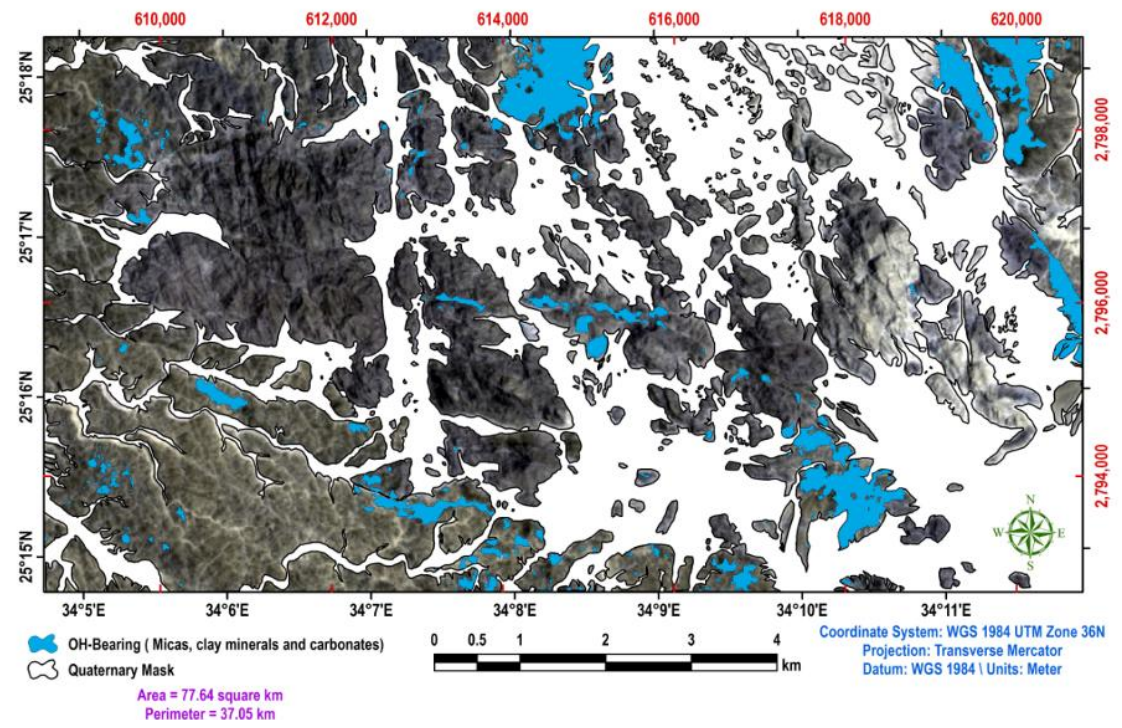

Fig.7. Showing Kaolinization map for Um Samra-Um Bakra area

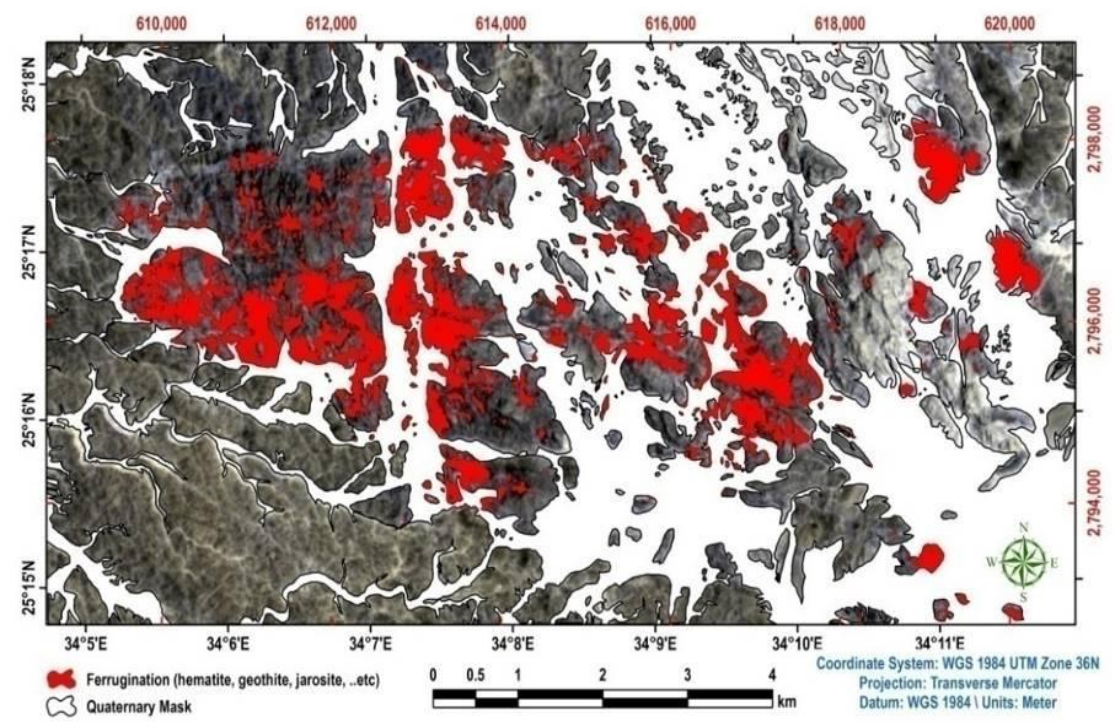

Fig.8. Showing ferrugination map for Um Samra-Um Bakra area

\section{Mineralogical Results}

Based on mineralogical study, Um Samra-Um Bakra area and the shear zone was classified into six main groups as illustrated in table (2) and represented by:

Table2. Shows the result of minerals occurrences in the study area

\begin{tabular}{|c|c|c|}
\hline Minerals group & Rock types / Veins & Minerals \\
\hline $\begin{array}{l}\text { Uranium } \\
\text { minerals }\end{array}$ & \multirow[t]{2}{*}{ Altered granite } & Meta-autunite, Phurcalite and Kasolite \\
\hline $\begin{array}{l}\text { Thorium } \\
\text { minerals }\end{array}$ & & Uranothorite \\
\hline \multirow{4}{*}{ Base Metals } & Altered granite & Wolframite \\
\hline & Black Jasper & $\begin{array}{c}\text { Cassiterite, Wolframite, Zincite, Ni-chromite and } \\
\text { Cr-spinel }\end{array}$ \\
\hline & Red Jasper & Ni-Chromite and Cr-spinel \\
\hline & Milky quartz & $\begin{array}{l}\text { Galena, Pyrite, covellite, bornite, pyrrhotite and } \\
\text { Sphalerite }\end{array}$ \\
\hline
\end{tabular}


Um Samra-Um Bakra Shear Zone, Central Eastern Desert, Egypt: Example of Vein -Type Base Metal Mineralization

\begin{tabular}{|c|c|c|}
\hline Copper Minerals & Black Jasper & Atacamite, Paratacamite, cuprite and crysocolla \\
\hline Native minerals & $\begin{array}{c}\text { Black Jasper and Milky } \\
\text { quartz }\end{array}$ & Gold and Nickel \\
\hline Nb-Ta minerals & Altered granites & Plumbopyrochlore, Columbite and Fergusonite \\
\hline \multirow{2}{*}{$\begin{array}{c}\text { Associated } \\
\text { Minerals }\end{array}$} & Altered granites & Zircon, Allanite, Rutile and Fluorite \\
\cline { 2 - 3 } & Black Jasper & Xenotime \\
\cline { 2 - 3 } & Red Jasper & --------------------- \\
\hline
\end{tabular}

\subsection{Radioactive Minerals}

\subsubsection{Uranium Minerals}

Uranium content in mineralized altered granites ranges between 32 and $8600 \mathrm{ppm}$ with average $=$ $2185 \mathrm{ppm}$ and represented by : a) Meta-Autunite $\left[\mathbf{C a}\left(\mathbf{U O}_{2}\right)_{2}\left(\mathbf{P O}_{4}\right)_{2} \cdot \mathbf{3} \mathbf{H}_{2} \mathbf{O}\right]$ occurs in the altered granites along the shear zone as soft and lemon yellow with vitreous luster. The EDX data of metaautunite shows $\mathrm{U}(61 \%), \mathrm{P}(15.15 \%), \mathrm{Ca}(4.88 \%)$, and $\mathrm{Si}(4.40 \%)$ are the main components(Fig.9a).b)Phurcalite $\left[\mathbf{C a}_{2}\left(\mathbf{U O}_{2}\right)_{3}\left(\mathbf{P O}_{4}\right) \mathbf{2}(\mathbf{O H})_{4} \cdot \mathbf{4 H}_{2} \mathbf{O}\right]$ associated with meta-autunite as soft, yellow and pale yellow with pale yellow streak and vitreous luster. The EDX data of phurcalite shows U (65.02\%), P (9.48\%), $\mathrm{Ca}(8.66)$ and $\mathrm{Si}(7.76 \%)$ are the main constituents (Fig.9b).c) Kasolite $\left[\mathrm{Pb}\left(\mathrm{UO}_{2}\right) \mathrm{SiO}_{4}\left(\mathrm{H}_{2} \mathrm{O}\right)\right]$ is found as massive grains with yellow to brownish yellow color and pale yellow streak (Fig. 9c).

\subsubsection{Thorium Mineral}

Thorium content ranges from 11- $242 \mathrm{ppm}$ with average $96 \mathrm{ppm}$ in altered granites and represented by uranothorite $\left[(\mathbf{T h}, \mathbf{U}) \mathbf{S i O}_{4}\right]$. It has dark yellow brown to pale brownish color. It is noted that the separated uranothorite is common in minute crystals associated with mica in the altered granites. The EDX data of investigated mineral shows Th- contents is $(63.39 \%)$ and $U(12.28 \%)$ as the main constituents (Fig. 9d).

\subsection{Base Metals}

Galena $[\mathrm{PbS}]$ presents in the mineralized quartz veins intruded the fresh granites as visible flakes and massive cubic crystals. The EDX data of galena shows $\mathrm{Pb}(40.30 \%)$ and $\mathrm{S}(19.59 \%)$ are the main components (Fig.10a).Pyrite [ $\left.\mathbf{F e S}_{2}\right]$ associated with galena in quartz veins as visible massive cubes and flakes of pale brassy yellow color with metallic luster. The EDX data of pyrite shows the Fe up to $(29.13 \%)$ with S element are the main components (Fig.10a).Sphalerite [(Zn, Fe)S] recorded in mineralized quartz veins, usually associated with galena and pyrite. EDX analysis gives $54.2 \%$ of $\mathrm{Zn}$ and $30.73 \%$ of $\mathrm{S}$ (Fig. 10b).Cassiterite $\left[\mathbf{S n O}_{2}\right]$ occurs in black jasper veins as dark brown color, opaque, metallic and adamantine luster. The EDX data of cassiterite (Fig.10c) shows its main constituents as $\mathrm{Sn}(81.07 \%)$.Wolframite $\left[(\mathbf{F e}, \mathbf{M n}) \mathbf{W O}_{4}\right]$ found in altered granites in brownish black color, anhydral granular and associated with iron minerals. It gives by EDX analysis $45.71 \%$ of W, $16.65 \%$ of $\mathrm{Fe}$ and $6.61 \%$ of Mn (Fig.10d). Zincite [ZnO] occurs in black jasper. It gives $42.13 \%$ of Zn (Fig.10e).Ni-Chromite [(Ni $\left.\mathbf{C r}_{2} \mathbf{O}_{4}\right)$ ] recorded in red jasper as dark black color grain, opaque, granular and metallic to greasy luster. It was identified by XRD techniques (Fig.10f).Cr-spinel $\left[\mathrm{FeCr}_{2} \mathrm{O}_{4}\right]$ occurs in red and black jasper. The EDX data (Fig.10g) gives $13.14 \%$ of $\mathrm{Cr}$ and $33.39 \%$ of $\mathrm{Fe}$.

\subsection{Copper Minerals}

Atacamite $\left[\mathrm{Cu}_{2} \mathbf{C l}(\mathbf{O H})_{3}\right]$ observed in black jasper by nicked eye, easy to scratch and identified by EDX techniques. It contains $64.69 \%$ of $\mathrm{Cu}, 20.09 \%$ of $\mathrm{Cl}, 7.36 \%$ of $\mathrm{Ni}$ and $5.64 \%$ of $\mathrm{Co}$ (Fig.11a).Paratacmite $\left[\mathrm{Cu}_{2} \mathbf{C l}(\mathbf{O H})_{3}\right.$ ] minerals subjected to semi- quantitative analysis by EDX

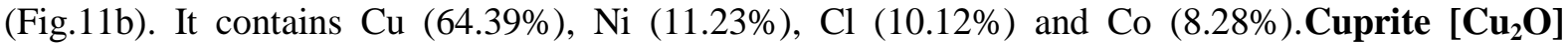
appears in black jasper veins as bright transparent red crystals, with glassy luster and pale-red streak. The EDX study of cuprite (Fig.11c) shows its main constituents are $\mathrm{Cu}$ (88.11\%) and $\mathrm{O}$ (11.89\%).Crysocolla [C $\left.\mathbf{C u}_{2}-\mathbf{x A l x}\left(\mathbf{H}_{2}-\mathbf{x S i} \mathbf{O}_{5}\right)\right]$ was confirmed by EDAX techniques (Fig.11d) and contains $\mathrm{Cu}(66.16 \%), \mathrm{Si}(31.65 \%)$ and $\mathrm{Ca}(2.19 \%)$

\subsection{Nb-Ta Minerals}

Columbite [(Fe, Mn) $\mathbf{N b}_{2} \mathbf{O}_{6}$ ] occurs in altered granites as opaque, dark brown to black massive grains and sub-metallic luster. Figure (12a) shows the EDX analyses of columbite which composed mainly of $\mathrm{Nb}(74.06 \%)$ and $\mathrm{Ta}(4.25 \%)$. 
Um Samra-Um Bakra Shear Zone, Central Eastern Desert, Egypt: Example of Vein -Type Base Metal Mineralization

Fergusonite [ $\left.\mathrm{YNbO}_{4}\right]$ observed in altered granites in dark brown, vitreous luster and pale-brown streak. It was investigated by EDX that illustrate presence of $\mathrm{Nb}(44.43 \%), \mathrm{Y}(24.14 \%)$ as main constituents, in addition to HREE as $\mathrm{Yb}(8.36 \%)$, Dy (7.13\%) and As (1.91\%) as shown in figure (12b).

Plumbopyrochlore $\left[(\mathbf{P b}, \mathbf{Y}, \mathbf{U}, \mathbf{C a})_{2}-\mathbf{x N b}_{2} \mathbf{O}_{6}(\mathbf{O H})\right]$ occurs in the altered granites in the shear zone . It contains $\mathrm{Pb}(36.72 \%), \mathrm{Nb}(36.09 \%), \mathrm{U}(16.77 \%)$ and $\mathrm{Y}(1.11 \%)$ in addition to ( $\mathrm{Si} 7.16 \%)$ and $\mathrm{Fe}$ $(1.5 \%)$ as given in (Fig.12c).
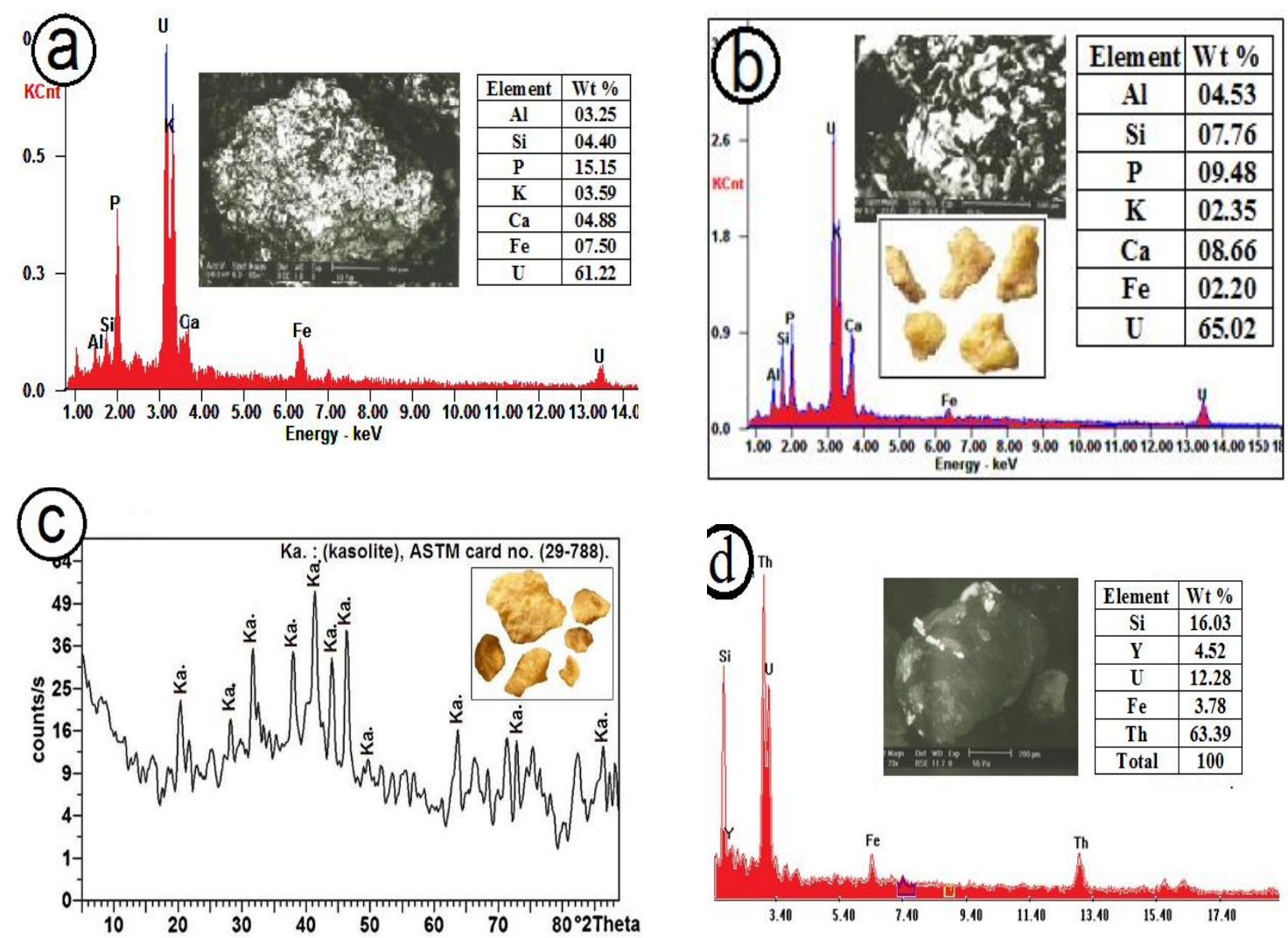

Fig.9. Showing EDX of a) meta-autunite, b) phurcalite minerals , c) XRD pattern of kasolite mineral and d) uranothorite at Um Samra-Um Bakra area.

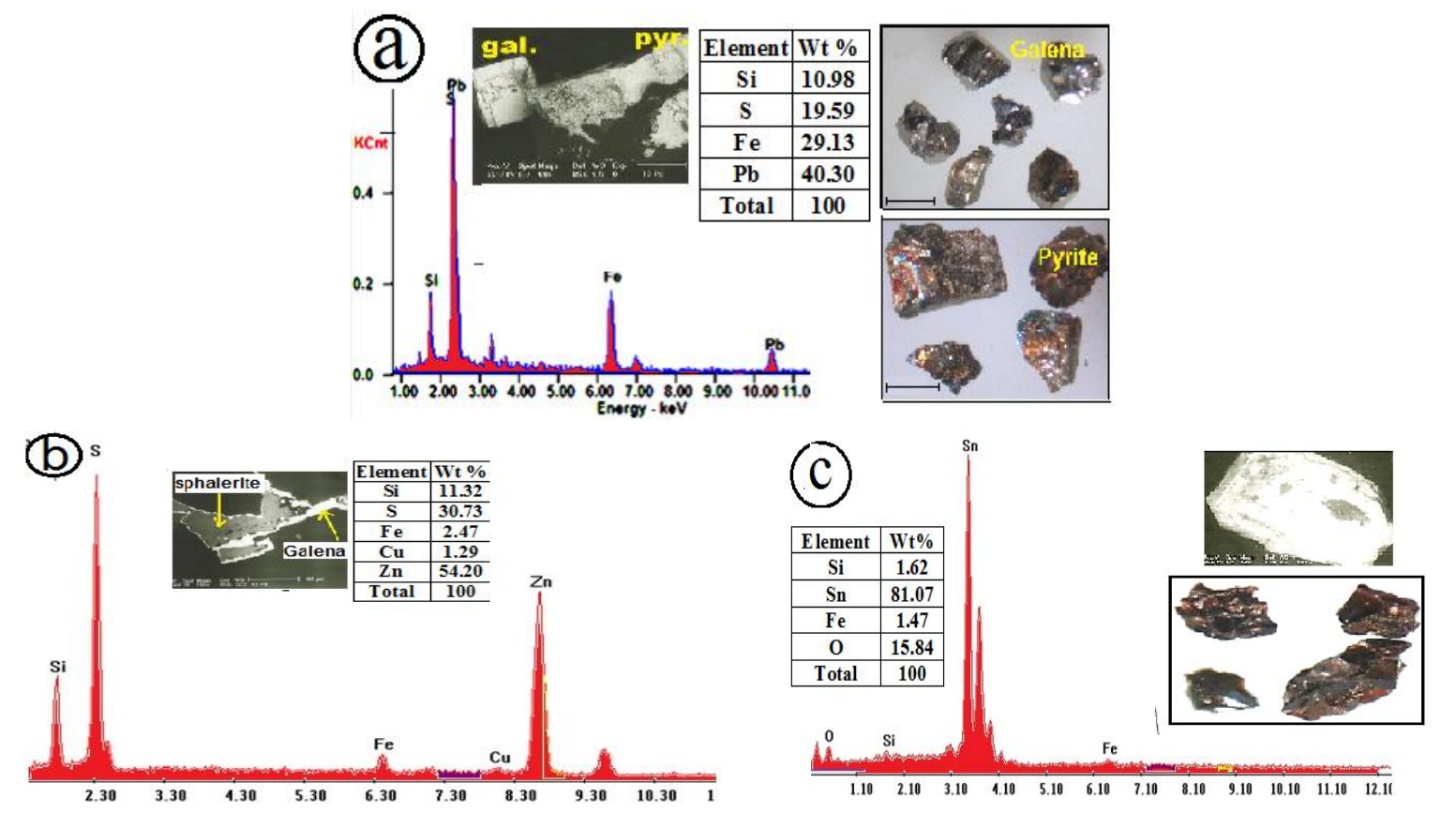



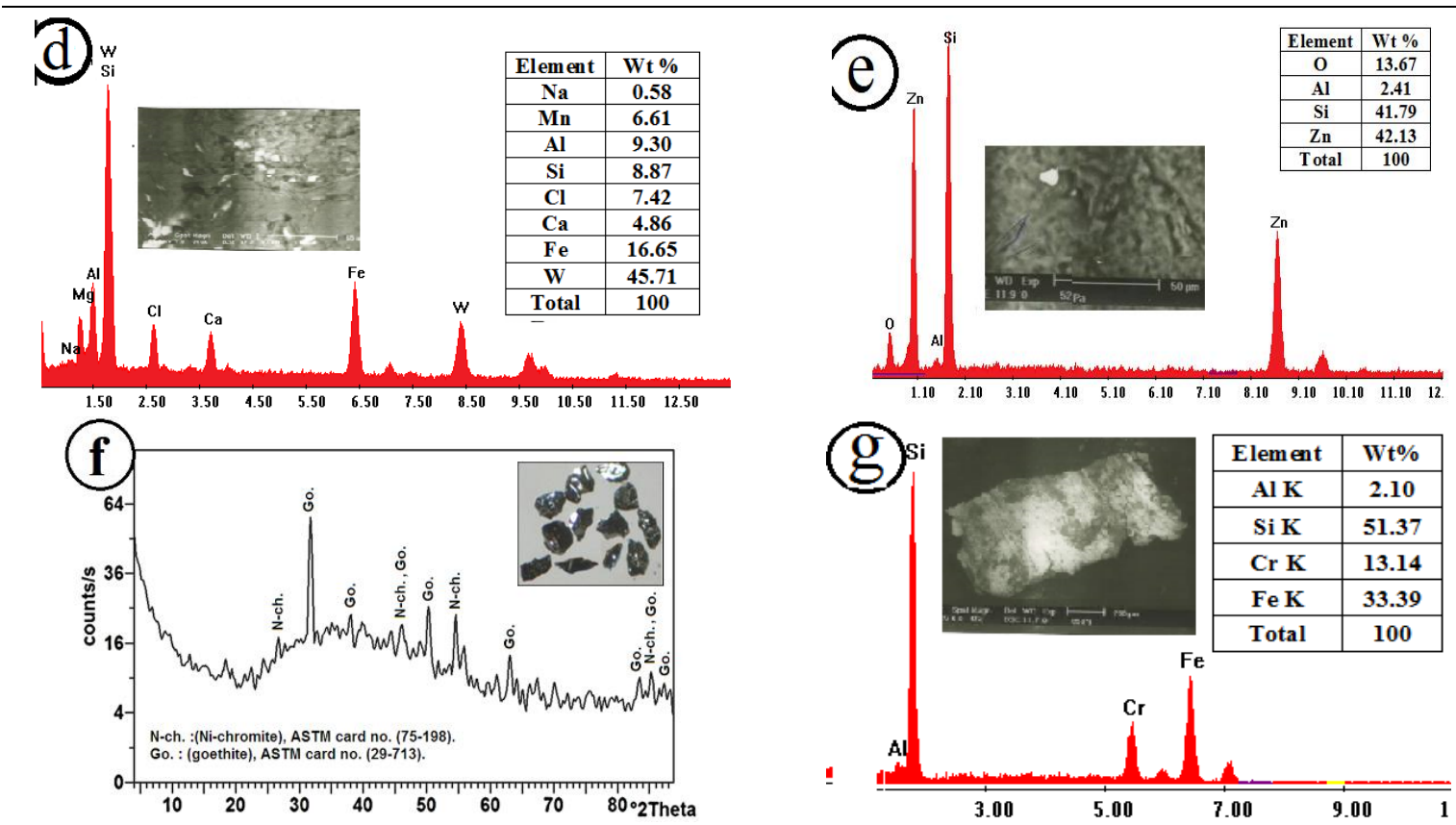

Fig.10. EDX analyses (a) galena and pyrite minerals, b) sphalerite, c) cassiterite, d) wolframite, e) zincite, $f$ ) XRD pattern of Ni-chromite mineral and g) EDX of Cr-spinel at Um Samra-Um Bakra area.
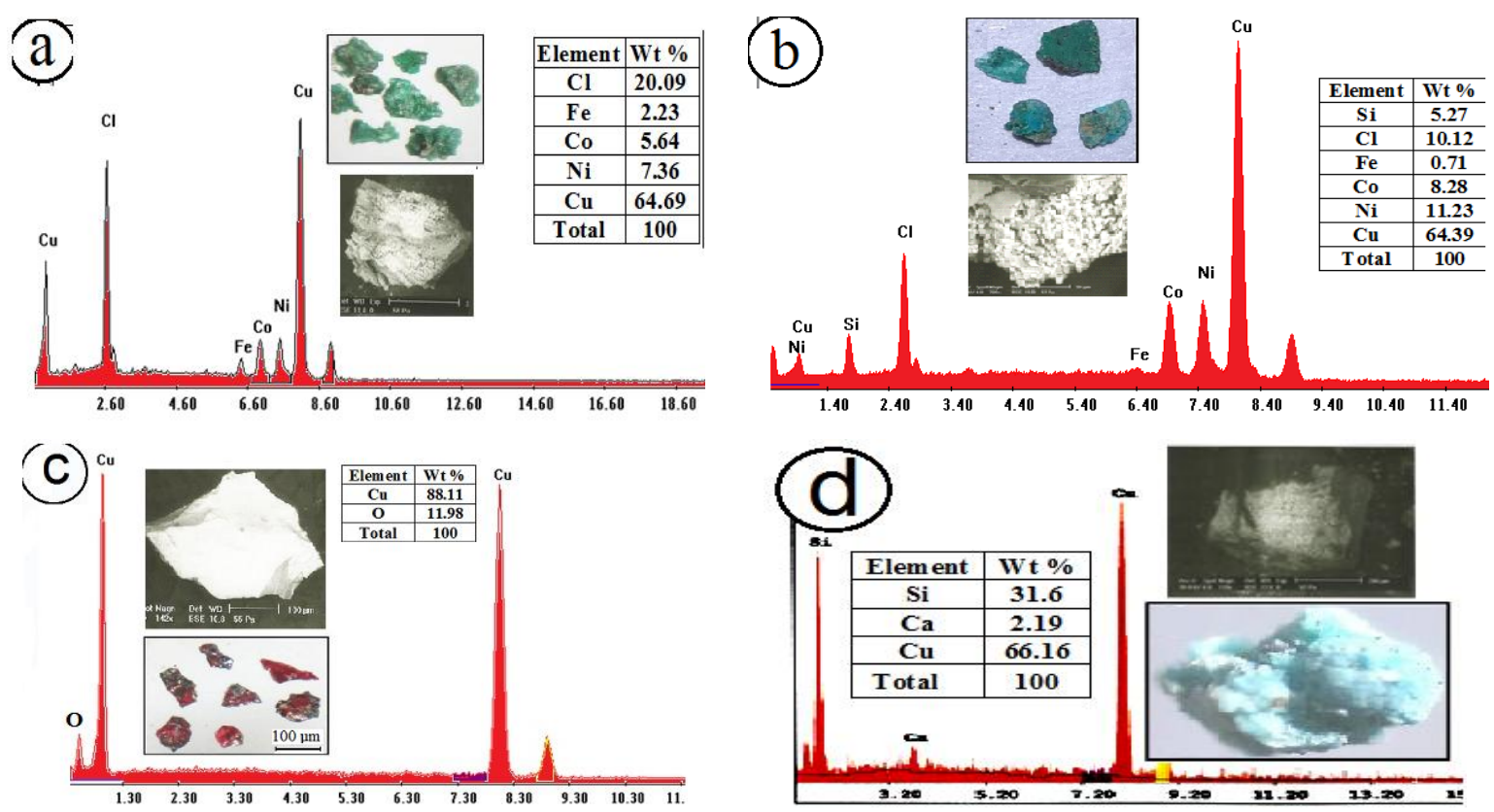

Fig.11. EDX analyses of copper minerals in red and black jasper, a): atacamite, b): paratacamite, c) cuprite mineral and d) crysocolla mineral at Um Samra-Um Bakra area.

\subsection{Native minerals}

Gold (Au) disseminated in both quartz veins which intruded fresh granites, and black jasper veins as native phase . EDX data shows Au contents (51.34\%) associated with $\mathrm{Cu}(6.45 \%)$ as given in figure (12d). Fire assay analyses for gold give $1.04 \mathrm{gm} / \mathrm{Ton}$. Nickel (Ni) observed in quartz and black jasper veins (Fig.12e) and up to (58.70\%).

\subsection{Associated Minerals}

Zircon $\left[\mathrm{ZrSiO}_{4}\right]$ is more abundance in altered granites and characterized by dark brown color and pale- brown streak. It contains $43.34 \%$ of $\mathrm{Zr}, 20.30 \%$ of $\mathrm{Th}, 18.36 \%$ of $\mathrm{Si}$, Fe up to $5.76 \%, 4.32 \%$ of $\mathrm{U}$, and Hf (1.98\%)(Fig.13a).

Monazite [(Ce,La,Nd,Th $\left.) \mathbf{P O}_{4}\right]$ recorded in the stream sediments as rounded to sub-rounded grains , translucent, vitreous luster and light brown color. The analyses show that the monazite are composed 
Um Samra-Um Bakra Shear Zone, Central Eastern Desert, Egypt: Example of Vein -Type Base Metal Mineralization

of $\mathrm{P}(51.59 \%), \mathrm{Ce}(30.26 \%), \mathrm{La}(15.26 \%), \mathrm{Nd}(14.14)$, Th (7.32\%) and $\mathrm{U}(1.74 \%)$ with rare of $\mathrm{Gd}$, Sm and Pr (Fig.13b).

Allanite $\left[(\mathbf{C e}, \mathbf{C a}, \mathbf{Y}, \mathbf{L a})_{2}\left(\mathbf{A l}, \mathrm{Fe}^{+3}\right)_{3}\left(\mathrm{SiO}_{4}\right)_{3}(\mathrm{OH})\right]$ occurs in altered granites as subhedral crystals of light brown color. The EDX data (Fig.13c) shows that allanite comprise Ce (16.75\%), Ca (10.18\%), $\mathrm{La}(9.18 \%)$ and $\mathrm{Nd}(4.58 \%)$.

Xenotime [YPO $\left.{ }_{4}\right]$ occurs as disseminated minutes in black jasper. The analyses (Fig. 13d) show that the presence of $\mathrm{P}(37.47 \%)$ and $\mathrm{Y}(36.01 \%)$ are the main constituents in addition to some HREEs as $\mathrm{Er}(6.08 \%)$ and $\mathrm{Yb}(4.73 \%)$ with traces of $\mathrm{Fe}(7.14 \%), \mathrm{Si}(6.37 \%)$ and $\mathrm{Ca}(1.72 \%)$

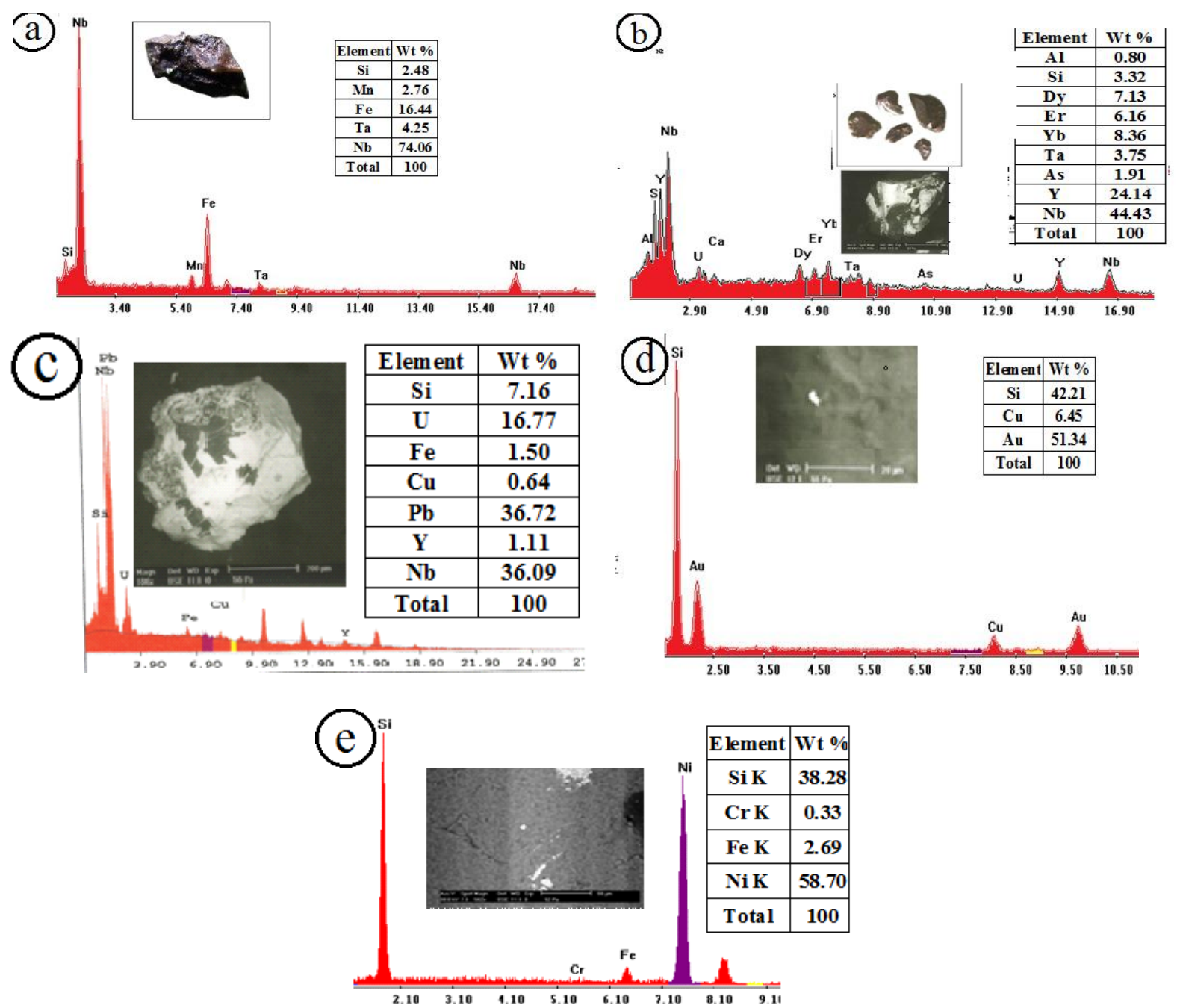

Fig.12. EDX analyses of a) columbite, b) fergusonite and c) plumbopyrochlore of the studied altered granites, d) native gold in milky quartz and black silica veins and e) native nickel in milky quartz and black jasper veins at Um Samra-Um Bakra area.
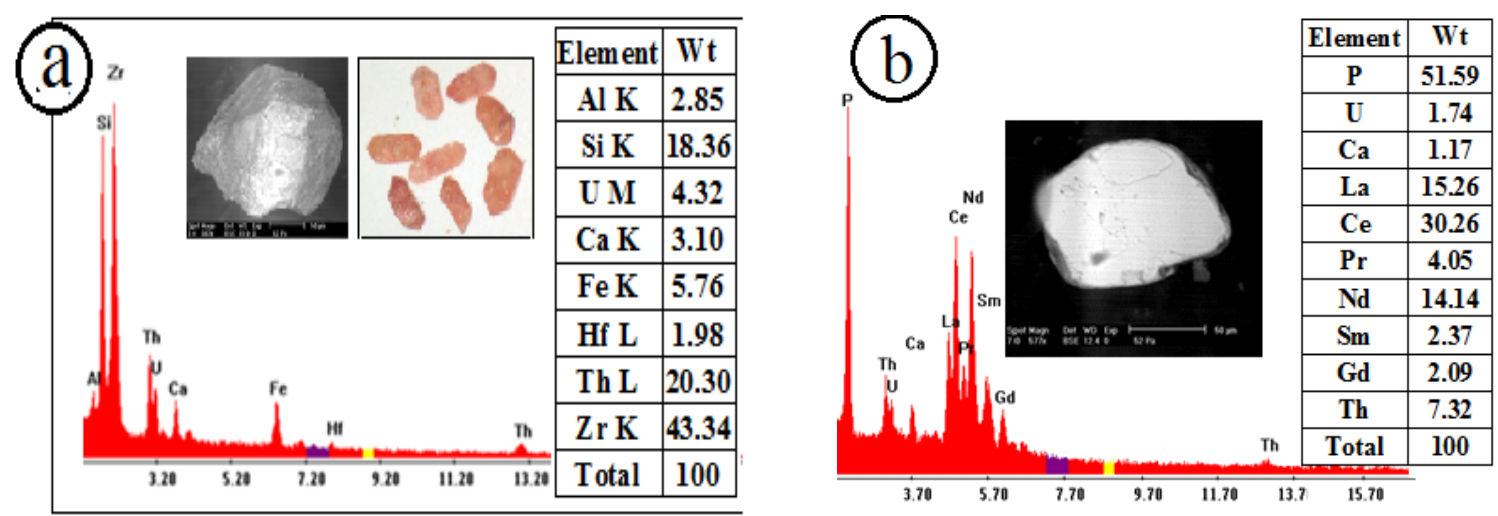


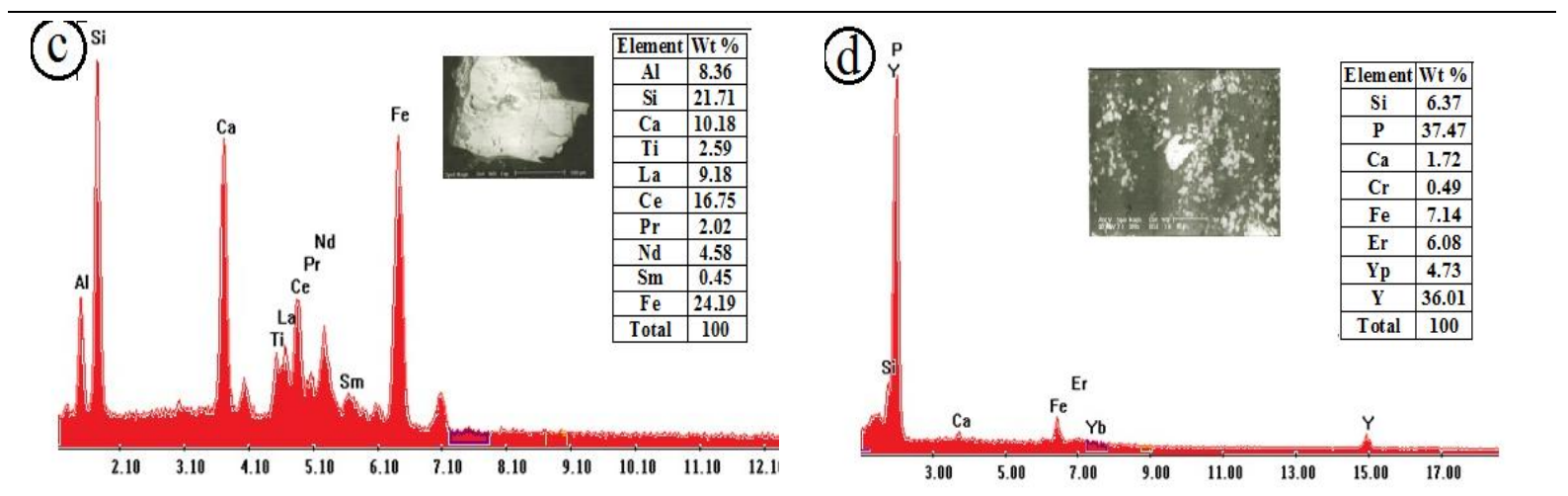

Fig.13. EDX analysis of a) zircon, b) monazite, c) allanite, and d) xenotime.

\section{DisCUSSION AND CONCLUSION}

- Formation a hydrothermal deposit in Um Samra-Um Bakra WNW-ESE shear zone requires: (a) a magma source of fluid, (b) dissolved metals in the magmatic fluids, (c) heat source and activate tectonic, causes the migration of fluid and (d) channel ways, layering and physical cavities, to precipitates the metals or minerals.

- Um Samra-Um Bakra shear zone strikes $\mathrm{N} 70^{\circ} \mathrm{W}-\mathrm{S} 70^{\circ} \mathrm{E}$ and dipping $45^{\circ} / \mathrm{SSW}$ and ranges from 10 to $500 \mathrm{~m}$ in thickness and extends $10 \mathrm{~km}$ in length. The host rock (Post- orogenic granite) is fine grained, highly altered, ferruginated, reddish pink and grayish pink to grayish in color.

- There are two types of milky quartz veins; a) barren milky quartz veins; are limited only to the Um Samra - Um Bakra shear zone and b) mineralized milky quartz veins; intruded monzo- to syenogranites and vary from white to pale gray in color, highly brecciated. These veins range between $0.3 \mathrm{~m}$ and $3 \mathrm{~m}$ in width, run ENE, WNW, E-W and N-S and dip $40^{\circ}-80^{\circ} / \mathrm{SE}, \mathrm{SSW}, \mathrm{S}$ and $\mathrm{E}$ direction respectively.

- Strike-slip faults dextral and sinistral sense of movement (N-S, NNE and NNW), forming grabben and horst structures respectively (6 $\mathrm{km}$ in length, $30 \mathrm{~m}$ in width, dipping $10^{\circ}-20^{\circ}$ towards $\mathrm{E}$ or $\mathrm{W}$ ) are good channel ways, cut Um Samra - Um Bakra shear zone .

- The mineralogical studies confirm the presence of three mineralization stages through ascending hydrothermal solutions at Um Samra - Um Bakra shear zone. The first stage (high temperature stage) characterizes by the formation of native Au associated with hypogene primary sulfide minerals such as pyrite, galena, sphalerite and nickel. The second stage (lower-temperature) is illustrates by the formation of secondary minerals; uranium, copper minerals (atacamite, paratacamite, crysocolla and cuprite), zincite, cassiterite, wolframite, Ni-chromite and $\mathrm{Cr}$-spinel. The third stage is related to carbonate facies (calcification, fluoritization) formed after the oxidation (supergene alteration).

- Gold is transported in solution as $\mathrm{Au}-\mathrm{Cl}$ and $\mathrm{Au}-\mathrm{S}$ complexes by ascending hydrothermal solution (supplementary to fluoritization) through channel ways(faults) and deposited at temperatures between $300^{\circ} \mathrm{C}$ and $400^{\circ} \mathrm{C}$ and pressures of 1 to $2 \mathrm{kbars}$ (Klemm et al. 2001). The change of physicochemical conditions such as temperature, pressure, oxygen fugacity, and sulfur fugacity are effective mechanisms for gold precipitation as(epithermal deposits). .

- Uranium minerals migrated from high topographic shear zone in the west to the east (low relief) by lateral solutions, transported through channel ways and redeposited on the surface and fissures of altered granites, and fixed by hematitization and kaolinitization. The presence of milky quartz veins on both sides of the shear zone prevents U- migration.

- Three generations of silica veins differ in color, mineralization and age, are common in the shear zone. The first phase (youngest), is barren milky quartz veins, running WNW and dipping $70 \%$ SSW direction, highly brecciated (2-5 Km in length, $0.25-3 \mathrm{~m}$ in width). The red jasper (second phase) has $\mathrm{N} 60^{\circ}-76^{\circ} \mathrm{W}$ trend, dipping $45^{\circ} / \mathrm{SSW}$ direction, fractured, fragmented, brecciated, (7 $\mathrm{km}$ in length, 0.30-3 $\mathrm{m}$ in width) and rich in $\mathrm{Cr}, \mathrm{Ni}, \mathrm{Sn}, \mathrm{Zn}$ and $\mathrm{Cu}-$ mineralization). The third phase (oldest one) is represented by black jasper $(1.8 \mathrm{~km}$ in length, $0.5-10 \mathrm{~m}$ in width, trends 
$\mathrm{N} 75^{\circ} \mathrm{W}$, dipping $50^{\circ}-65^{\circ} / \mathrm{SSW}$ and rich in $\mathrm{Cr}, \mathrm{Ni}$, and $\mathrm{Au}$ mineralization). The black jasper is richer than red one in $\mathrm{Ni}$ (av. $1004-81 \mathrm{ppm}$ ), $\mathrm{Cr}$ (av. 8575 -853ppm), Zn (av. $144-80$ ppm), Cu (av. 1107- $35 \mathrm{ppm}$ ), and $\mathrm{Au}$ (1.4 -0.5 ppm) respectively.

- The presence of clay mineral (dickite: $\mathrm{Al}_{2} \mathrm{Si}_{2} \mathrm{O}_{5}(\mathrm{OH})_{4}$ ) in quartz and jasper veins indicates a temperature environment higher than $200^{\circ} \mathrm{C}$. The mixing of volatile fluids with meteoric water and fluid- wall rock interaction result in changes in $\mathrm{pH}$ and oxygen activity and deposition of base metals.

- Precipitation of hematite in the shear zone and red jasper veins probably decreased the $\mathrm{pH}$ of the solution and rising acidic fluids. The sudden change in the $\mathrm{pH}$ and temperature of the fluids will lead to destabilization of base metal complexes favoring their deposition (Alexandrov et al., 1985).

- The cooling of the hydrothermal solution decreases the solubility of the metals. Cooling can take place when hot magmatic fluids enter cooler wall rocks or when two fluids mix, similar reactions can take place between hydrothermal solutions and wall rock; a solution containing dissolved sulfide might contact a rock containing magnetite, to convert the magnetite to pyrite by a process called sulfidation. Or, a solution containing $\mathrm{Cu}$ might react with a rock containing pyrite to form $\mathrm{Cu}$ sulfides.

- The base metals mineralization are accumulate in the residual melt of the late fractionate alkali feldspar granites (Bright, 1974) especially upward in the magmatic system (Smith, 1979). During the emplacement of the basic and intermediate dykes (olivine basalt, dolerite and andesite dykes) which accompanied with high temperature and $\mathrm{CO}_{2}$, the base metals (galena, pyrite, sphalerite and cassiterite) were precipitated from saline and reduced fluids as sulfides due to cooling, fluid mixing and wall rock reaction.

- The banded texture in jasper veins is common in epithermal base metals, indicating of boiling event and rapid deposition (Hedenquist et al., 1995). Low- temperature hydrothermal solutions $\left(<300{ }^{\circ} \mathrm{C}\right)$ can transport $\mathrm{Cr}, \mathrm{Ni}, \mathrm{As}, \mathrm{Ga}, \mathrm{U}, \mathrm{Co}$, and $\mathrm{Au}$ metals, and deposits them into the epithermal brecciated veins. The high concentrations of $\mathrm{Cr}, \mathrm{Ni}, \mathrm{Ga}, \mathrm{Zn}, \mathrm{Cu}, \mathrm{Co}, \mathrm{As}$ and $\mathrm{Au}$ in the jasper veins can be attributed to the ore fluids enriched in these components. We assume their ultimate source to the ultramafic and mafic rocks in the study area.

- The non-sulfide ore deposits are classified into two major types; supergene and hypogene deposits (Hitzman et. al., 2003). (a) supergene deposits are formed principally zinc carbonate or silicates, and (b) hypogene deposits consist dominantly of zinc silicates and oxides. Um Samra-Um Bakra shear zone containing zinc oxides (hypogene deposits).

- Pyrite present in two generations: disseminated and along fractures. The occurrence of covellite, bornite and magnetite are related to the oxidation product of disseminated pyrite, whereas the second type of pyrite transformed into pyrrhotite.

- The chloritization process is the last phase of alteration in the shear zone, where fluids became rich in $\mathrm{Mg} / \mathrm{Fe}$ most probably due to the decomposition of ferromagnesian minerals from the basic and intermediate dykes.

\section{ACKNOWLEDGEMENT}

Our sincere thanks and gratitude should be provided to Dr. W. El-Ghazlawy, NMA, for assistance during field work.

\section{REFERENCES}

[1] Abdalla, H. M., Matsueda, H., Obeid, M., A. and Takahashi, R. (2008): Chemistry of cassiterite in rare metal granitoids and the associated rocks in Eastern Desert, Egypt. Jour. of Min. and petr. sci., 103, 318 $326 \mathrm{p}$.

[2] Abdel Monem, A. A., Shazly, A. G., Salem, I. A., Ashmaway, M. H. and El Shibiny N. H. M. (1999): Petrographical and geochemical characteristics of some granitoids associated with rare-metal mineralizations, Central Eastern Desert, Egypt. 4th Inter. Conf. Geoch, Alexandria Univ., Egypt 243-260p. 
[3] Abu Dief, A. (1985): Geology of Uranium Mineralization in Missikat, Qena-Safaga Road, Eastern Desert, Egypt. Un- published M.Sc. Thesis, Assiut Univ., Assiut, 242 p.

[4] Abu Deif A. and El-Tahir, M. (2008): A new uranium occurrence, Gabal ElMissikat Prospect, Central Eastern Desert, Egypt. JKAU: Earth Sci V.19. 85-97p.

[5] Akaad, M. K. and Noweir, A. M. (1980): Geology and lithostratigraphy of the Arabian desert orogenic belt of Egypt between latitudes $25^{\circ} 35^{\prime}$ and $26^{\circ} 30^{\prime}$ N. Precambrian Res 6: A6.

[6] Alexandrov, I.V., Krasov, A.M., and Kochnova, L.N. (1985): The effects of K, Na and F on rock- forming mineral assemblages and the formation of tantalo-niobate mineralization in rare-element granite pegmatites. Geoc 4.

[7] Bakhit, F.S. (1978): geology and radioactive mineralization of Gabal El-Missikatarea,Eastern Desert of Egypt, A.R.E. Ph.D. thesis, Fac. Sci., Ain Shams Univ., Cairo, Egypt, 289 p.

[8] Bakhit, F.S. and Meleik, M.L. (1990): Application of autocorrelation functions to structural lineaments in radioactive sample area in the Central Eastern Desert of Egypt. Int. G. Remote Sensing, 11, No. 10,1919.

[9] Bright, M. J. (1974): Primary geochemical dispersion associated with the Henderson molybdenum deposit, Colorado. Abst., Econ. Geol., 69, 1177.hem. Internat., 22, 85-92p.

[10] Cuney, M., Le Fort, P. and Wong, Z. X. (1984): Uranium and thorium geochemistry and mineralogy in the Manaslu leucogranites (Nepal, Himalaya): Geology of Granites and their Metallogenic Relations: Symp. Nanjing, 1982. Univ. Press, Beijing, 853-873p.

[11] El Ramly, M. F. (1972): A new geological map for the basement rocks in the South Western Desert of Egypt. Ann. Geol. Surv. Egypt.2, 1-18p.

[12] Greenberg, K. E. (1981): Characteristics and origin of Egyptian Younger granites. Geol. Soc. Am. Bull., 92, 749-840p.

[13] Hassan, M. A. and El Shatoury, H.M. (1976): Beryl occurrences in Egypt: (Egyptian) Minining Geology, 26, 253-262p.

[14] Hassan, M. A. and Hashad, A. H. (1990): Precambrian of Egypt, in Said, R. (ed.), The Geology of Egypt: A. A. Balkema, Rotterdam, Netherlands, 201-245p.

[15] Haynes, D.W., Brooke, W.J.L. and Mazzoni, P.P. (1993): Application of conceptual models for sediment hosted ore deposits in the discovery of the Nifty copper and adjacent lead-zinc deposits, Yeneena Basin, Western Australia. In: Kirkham, R.Y., Sinclair, W.D., Thorpe, R.I. \& Duke, J.M. (editors), Mineral deposit modeling. Geological Association of Canada, Special Paper 40,75-88.

[16] Hedenquist, J.W., Izawa, E., Arribas, A. and White, N.C. (1995): Epithermal gold deposits: Styles, characteristics and exploration. Resource Geology No. 1, Tokyo. 12 p.

[17] Helgeston, H. C. (1974): Chemical interaction of feldspars and aqueous solution in the feldspars. In: Mackenzie WL, Zussman J (eds) Manchester University Press, Manchester, 184-215p.

[18] Hemley, J. J. and Jones, W. R. (1964): Chemical aspects of hydrothermal alteration with emphasis on hydrogen metasomatism. Econ Geol 59: 538-569p.

[19] Hussein, A. A., Ali, M. M. and El Ramly, M. F. (1982): A proposed new classification of the granites of Egypt, j. and Geoth. Res., 14, Elsevier, Amsterdam: 187-198.

[20] Hitzman, M.W., Reynolds, N.A., Sangster, D.F., Allen, C.R. and Carman, C.E. (2003): Classification, genesis, and exploration guides for non-sulfide zinc deposits. Economic Geology, vol. 98, 685-714p.

[21] Hussein, A. M. and Sayyah, T.A. (1991): Uranium of the younger granites of Egypt. Inter. Atomic Energy. Vienna, Austria, 14p.

[22] Ibrahim, I. H. (2001): Geology, geochemistry and potentiality of radioactive mineralizations at Um Safi area, Central Eastern Desert, Egypt. Ph.D. Thesis, Ain Shams Univ of Egypt, 288p.

[23] Ibrahim, M .E. , Zalata, M. A., Ibrahim, I. H. and Rashed, M. A. (2003): El Sella Shear Zone, Southeastern Desert, Egypt; An Example of Vein-type Uranium Deposit. Egyptian Journal of Geology, Vol. 47/2, 689-704p.

[24] Kabesh, M. L., Salem, A. A., Heikal, M. A. and Salem, M. A. (1982): Petrochemistry and Petrogensis of the granitic rocks of Um Samra pluton, Eastern Desert, Egypt. J Geol 26: 171-184. 15p.

[25] Klemm, D.D., Klemm, R., Murr, A., (2001): Gold of the Pharaohs - 6000 years of gold mining in Egypt and Nubia. Journal of African Earth Sciences V.33, P.643-659.

[26] Pirajno, F. (1992): Hydrothermal Mineral Deposits. Principles and Fundamental Concepts for the Exploration Geologist. xviii +709 pp. Berlin, Heidelberg, New York, London, Paris, Tokyo, Hong Kong: Springer-Verlag. Price DM 248.00 (hard covers). ISBN 3540525173. 
[27] Kroner, A., Greiling, R., Reischmann, T., Hussein, I. M., Stern, R. J., Durr, S., Kruger, J. and Zimmer, M. (1987): Pan-African crustal evolution in northeast Africa. In: Kroner, A. (ed.) Proterozoic lithosphere evolution.American Geophysical Union, Geodynamic Series, 17, 235-257p.

[28] Moghazi, A. M., Andersen, t., Oweiss, G.A. and Elbouseily, A. M. (1998): Geochemical and Sr-Nd-Pb isotopic data bearing on the origin of Pan African granitoites in the Kid area, southeast Sinai, Egypt. J. Geol. Soc. London., 155, 697-710p.

[29] Saleh, G. M., Kamar, M. S., Rashed, M. A. and El-Sherif, A.M. (2015): Uranium Mineralization and Spectrometric Prospecting along Trenches of Um Safi area Central Eastern Desert of Egypt. Geoinfor Geostat: An Overview, 3:1

[30] Shazly, A. G., Salem, I. A., Abdel Monem, A. A. and El Shibiny, N. H. (1998): Ore mineralogy, geochemistry and fluid inclusions of some gold bearing quartz veins in the Central Eastern Desert of Egypt. Egypt Min 10: 51-74. 16p.

[31] Smith, R. L. (1979): Ash-flow magmatism. Geol. Soc. Amer. Spec. Paper 180, 5-27p.

[32] Stern, R. J. and Hedge, C. E. (1985): Geochronologic and isotopic constraints on Late Precambrian crustal evolution in the Eastern Desert of Egypt. Am. Jour. Sci. 285: 97-127p.

Citation: Ibrahim, M.E. et al. (2017). Um Samra-Um Bakra Shear Zone, Central Eastern Desert, Egypt: Example of Vein -Type Base Metal Mineralization, International Journal of Mining Science (IJMS), 3(2), pp.9-25, DOI: http://dx.doi.org/10.20431/2454-9460.0302002

Copyright: () 2017 Ibrahim, M.E. This is an open-access article distributed under the terms of the Creative Commons Attribution License, which permits unrestricted use, distribution, and reproduction in any medium, provided the original author and source are credited 